\title{
Polyphase tectonic subsidence evolution of the Vienna Basin inferred from quantitative subsidence analysis of the northern and central parts
}

\author{
Eun Young Lee ${ }^{1} \cdot$ Michael Wagreich $^{1}$
}

Received: 5 March 2015 / Accepted: 6 April 2016 / Published online: 20 April 2016

(C) The Author(s) 2016. This article is published with open access at Springerlink.com

\begin{abstract}
The Vienna Basin is a tectonically complex Neogene basin situated at the Alpine-Carpathian transition. This study analyzes a detailed quantification of subsidence in the northern and central parts of the Vienna Basin to understand its tectonic subsidence evolution. About 200 wells were used to arrange stratigraphic setting, and wells reaching the pre-Neogene basement were analyzed for subsidence. To enhance the understanding of the regional subsidences, the wells were sorted into ten groups based on their position on major fault blocks. In the Early Miocene, subsidence was slow and along E-W to NE-SW trending axis, indicating the development of thrust-controlled piggyback basins. During the late Early Miocene data show abruptly increasing subsidence, making the initiation of the Vienna pull-apart basin system. From the Middle Miocene, the tectonic subsidence curves show regionally different patterns. The tectonic subsidence during the Middle Miocene varies laterally across the Vienna Basin, and the differential subsidence can be related to the changing tensional regime of weakening transtension and strengthening extension toward the late Middle Miocene. From the late Middle Miocene to the Late Miocene, the tectonic subsidence occurred dominantly along the regional active faults, and corresponds to the axis of $\mathrm{E}-\mathrm{W}$ trending extension of the western parts of the Pannonian Basin system. In the Quaternary the Vienna Basin has been reactivated, and resulted in subsidence along the NE-SW trending Vienna Basin transfer fault system.
\end{abstract}

Eun Young Lee

eun.lee@univie.ac.at

1 Department of Geodynamics and Sedimentology, University of Vienna, Althanstrasse 14, 1090 Vienna, Austria
Keywords Vienna Basin $\cdot$ Pull-apart basin · Piggyback basin $\cdot$ Subsidence $\cdot$ Polyphase basin evolution $\cdot$ Pannonian basin system

\section{Introduction}

The Vienna Basin (central Europe) is situated on top of the Alpine fold and thrust belt, located at the junction between the Eastern Alps, the Carpathians, and the Pannonian Basin system (Fig. 1). It is interpreted as a classical thin-skinned pull-apart structure formed during Miocene lateral extrusion of the Eastern Alps (e.g., Mann et al. 1983, 1995; Royden 1985; Decker et al. 2005; Hinsch et al. 2005). The rhombic basin is about $200 \mathrm{~km}$ long and $60 \mathrm{~km}$ wide, and formed mainly along the sinistral Vienna Basin transfer system (Royden 1985; Wessely 1988; Decker 1996; Decker and Peresson 1996; Strauss et al. 2006). This more than $300 \mathrm{~km}$ long strike-slip fault system is one of the most conspicuous crustal structures between the Eastern Alps and the Carpathians (Decker et al. 2005).

The basin has been studied intensively starting with classical paleontological-stratigraphical papers and then continuing since the beginning of hydrocarbon exploration at about 100 years ago. Studies focused mainly on the southern and central parts (Austrian part) of the basin for a variety of reasons. However, a comprehensive detailed study crossing the borders of Austria, Slovakia, and Czech Republic is still missing. The northern and central parts (Czech and Slovakian parts) are highly important to understand the overall stratigraphic and structural evolution of the basin, because these parts contain up to $6 \mathrm{~km}$ of the Miocene sedimentary rocks, several complex structures, and the Steinberg fault, one of the most prominent structure features of the basin (e.g., Decker 1996). 
This study analyzed a more detailed regional subsidence history of the northern and central parts of the basin to understand the tectonic evolution. Furthermore, the results of this study are compared with previous studies conducted in the southern part. Several publications studied the subsidence history of the Vienna Basin (e.g., Sclater et al. 1980; Royden 1985; Lankreijer et al. 1995; Wagreich and Schmid 2002; Hölzel et al. 2008; Lee et al. 2011). However, these studies either cover the basin locally or focus more on surrounding areas with sparse well data. Compared to other publications on this topic, our study covers an extensive region of the basin and provides a more accurate analysis through the high density of considered boreholes, the geophysical evaluation for more realistic porosity-depth relations, and the mapping by employing a 2D/3D interpolation technique.

\section{Geologic setting}

The Vienna Basin has a rhombohedral shape with the leftstepping pattern of en-echelon faults (Royden 1985). Along the western flank, the Schrattenberg-Steinberg-Bisamberg-Leopoldsdorf fault systems separated a system of depressions from the western marginal blocks (Fig. 1). Geographically, the Vienna basin is subdivided in three parts. The northern part covers the area north of the Kuty graben. The central part extends from the Kuty graben to the Schwechat depression, including the Zistersdorf depression. The southernmost part of the Vienna basin covers the area south of the Schwechat depression, including the Wiener-Neustadt basin and the Mitterndorfer depression (Lankreijer et al. 1995).

This study uses the regional Central Paratethys chronostratigraphy for the Miocene (e.g., Piller et al. 2007; Hohenegger et al. 2014) and regional and local zonations for the Vienna Basin (Fig. 2). The Paratethys was a partly enclosed sea that existed from Oligocene to Miocene times to the north of the Alpine mountain belt, and consisted of a chain of basins of various tectonic origin (e.g., Piller et al. 2007). The Central Paratethys covered the area from Bavaria to the Eastern Carpathians (Báldi 1980).

The Vienna Basin tectonic evolution has a complex history due to the position of the basin which is bordered by the Eastern Alps in the west, the Western Carpathians in the northeast, and the Pannonian Basin system in the southeast (Fig. 1). The Eastern Alps and the Western Carpathians formed by collisional orogenies during the Mesozoic and the Cenozoic (Decker and Peresson 1996; Plašienka et al. 1997; Royden 1988). The Pannonian Basin system is a result of Middle to Late Miocene lithospheric extension (Sclater et al. 1980; Royden et al. 1983a, b). The AlpineCarpathian-Pannonian system was deformed by the late
Paleogene and Neogene lateral extrusion of the Eastern Alps toward the Pannonian area in the east (Ratschbacher et al. 1991a, b). The extrusion caused complex and polyphase strike-slip faulting and back-arc-extension linked to the retreating subduction zone, and further resulted in development of Miocene pull-apart basins (e.g., Vienna Basin) and extensional rift basins (e.g., Pannonian basin) (Royden et al. 1983a, b; Royden 1985, 1988; Csontos et al. 1992; Horváth 1993; Mann et al. 1995; Decker and Peresson 1996; Huismans et al. 2001).

The Vienna Basin has been influenced by the evolution of each of these geologic systems. The basin is characterized by four distinct tectonic phases; (1) Early Miocene piggyback basin, (2) Middle-Late Miocene pull-apart basin, (3) Late Miocene-Pliocene compression and basin inversion, and (4) Quaternary basin formation (Beidinger and Decker 2011; Decker et al. 2005; Peresson and Decker 1997a, b; Salcher et al. 2012; Seifert 1992; Strauss et al. 2006). Each phase is associated with a distinctive geographic axis of subsidence.

\section{Early Miocene piggyback basin}

In the Early Miocene (c. $20-17 \mathrm{Ma}$ ), several E-W trending small sub-basins subsided on the frontal parts of the $\mathrm{N}$ - to NW-propagating thrust belt of the Eastern Alps. This basin stage was active from the Eggenburgian to the early Karpatian (Decker 1996; Fodor 1995; Jiř́ček and Seifert 1990; Seifert 1992, 1996). It is described as piggyback basin (wedge-top basin, Ori and Friend 1984), formed on top of active thrust sheets. Although the Eggenburgian sediments were restricted to the northern part of the Vienna Basin, during the Ottnangian and the early Karpatian the sedimentation spread to the central part (Decker 1996; Jiříček and Seifert 1990; Strauss et al. 2006).

\section{Middle-Late Miocene pull-apart basin}

At the end of the Early Miocene (c. 17-16 Ma), the Vienna Basin became a pull-apart structure (Fodor 1995; Decker 1996). Structural styles within the pull-apart were dominated by NE-SW trending sinistral strikeslip duplexes and en-echelon listric normal faults with a left-stepping geometry at the Vienna Basin transfer fault (Royden 1985, 1988; Decker et al. 2005). The main tectonic elements are the Steinberg fault $(5.6 \mathrm{~km}$ normal offset), the Leopoldsdorf fault (4.2 km normal offset), the Laksary fault, the Farsky fault, and the Lanzhot-Hrusky fault (Čekan et al. 1990; Wessely et al. 1993; Decker et al. 2005) (Figs. 1, 6). Growth strata along normal faults indicate that faulting occurred synsedimentary during the late Early and Middle Miocene (Decker 1996). The geodynamic processes resulted in an intricate arrangement of 


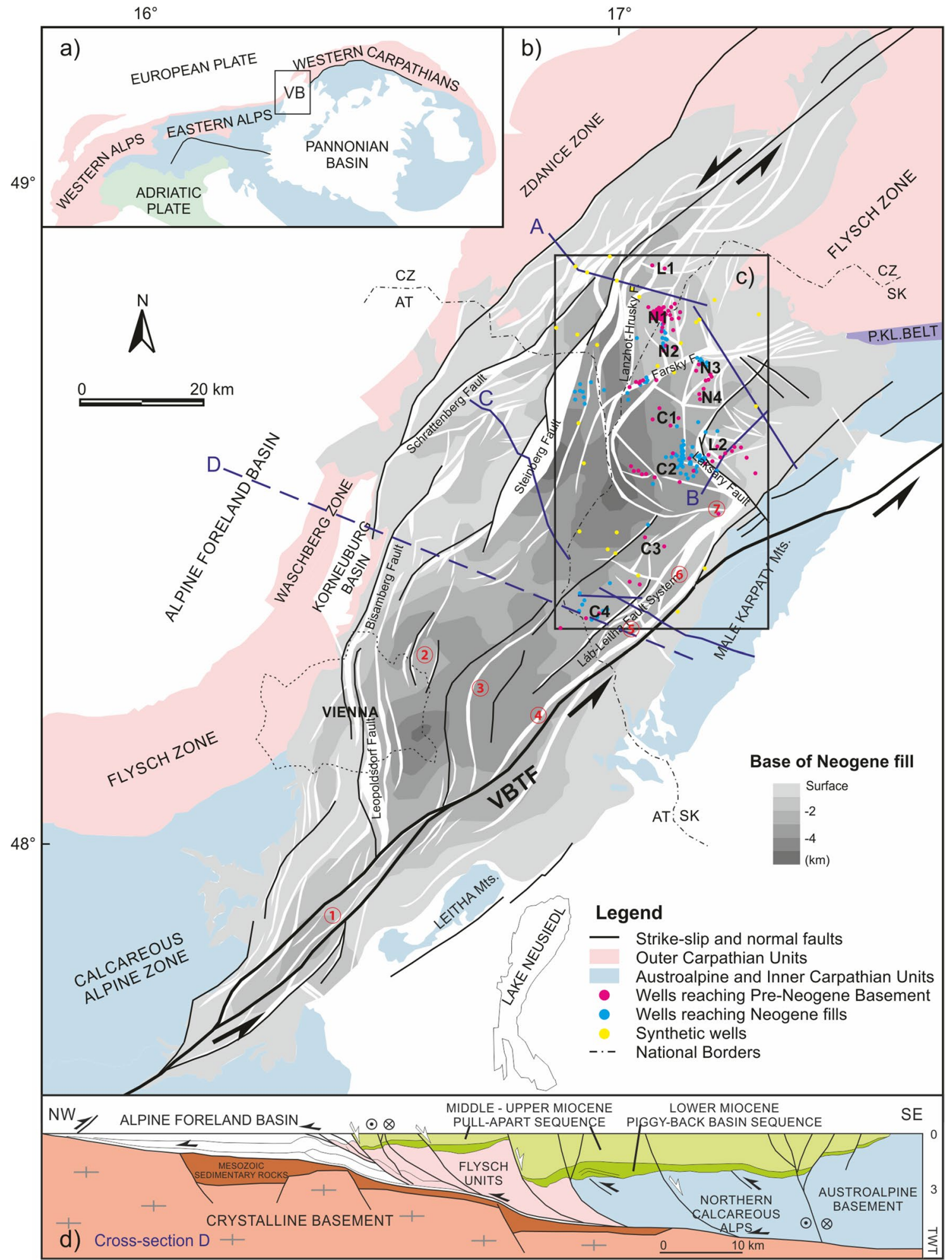

Fig. 1 a Tectonic sketch map of the east Alpine-west Carpathian region. b The structure map of the Vienna Basin showing the faulted pre-Neogene basement surface and the base depth of the Neogene fill (modified from Wessely et al. 1993; Arzmüller et al. 2006). Locations of section $A, B, C$, and $D$ are shown. Quaternary basins are arranged along the Vienna Basin transfer fault system (VBTF); (1) Mitterndorf Basin, (2) Aderklaa Basin, (3) Obersiebenbrunn Basin,
(4) Lassee Basin, (5) Zohor Basin, (6) Pernek Basin, and (7) Sološnica Basin (Beidinger and Decker 2011). AT: Austria, SK: Slovakia, CZ: Czech Republic. c Location of the area mapped in Figs. 7, 12, and 15. Letters $L 1-C 4$ denote well groups distinguished in this study. d A geologic profile (section $D$ in Fig. 1b) through the Molasse and the Vienna Basin depicting thrust units (modified from Beidinger and Decker 2014) 
Fig. 2 Stratigraphy and evolution of the Vienna Basin (Fodor 1995; Decker 1996; Peresson and Decker 1997a, b; Hamilton et al. 2000; Wagreich and Schmid 2002; Hölzel et al. 2010; Hohenegger et al. 2014)

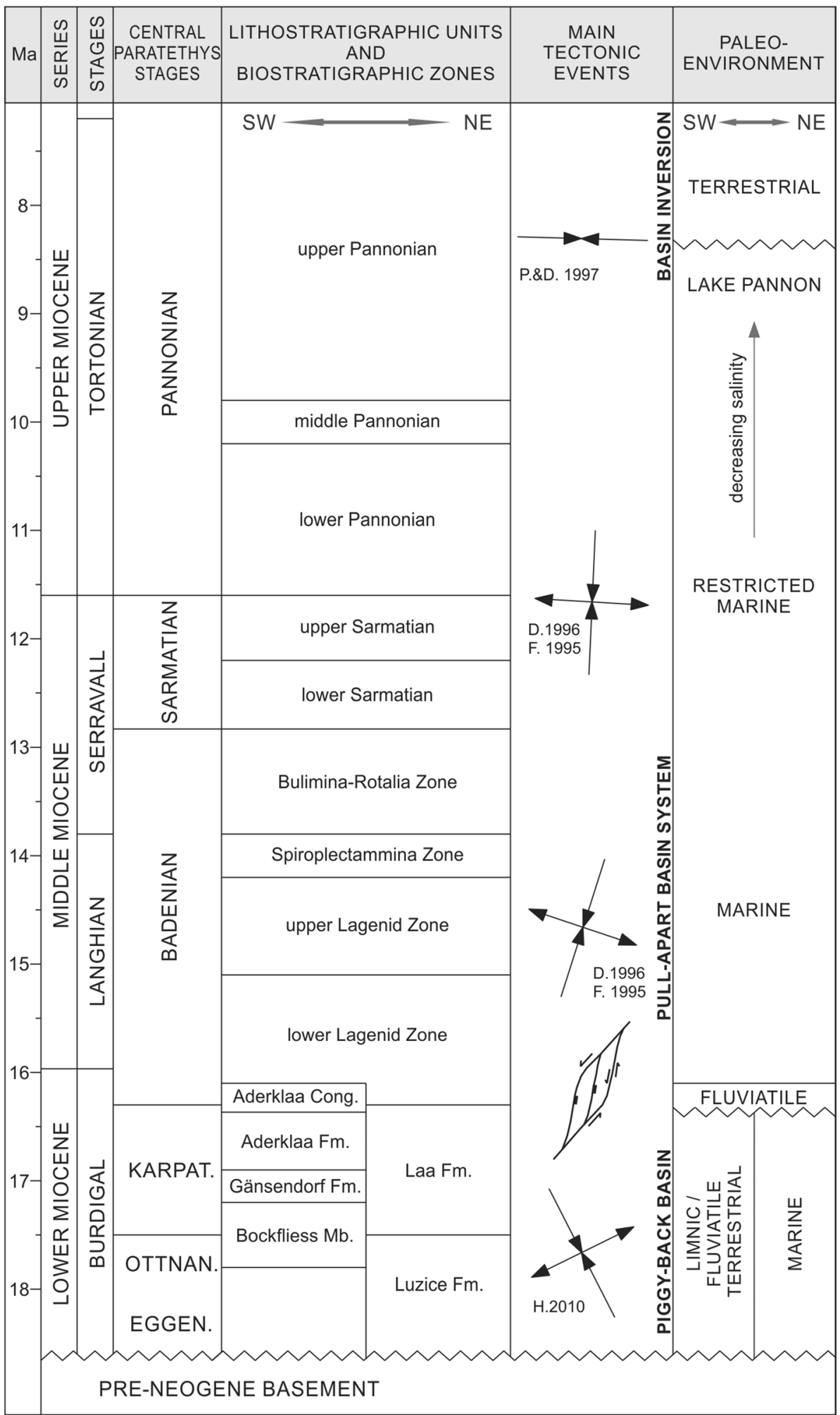

prominent highs and partly deeper subsided depocenters (Hölzel et al. 2008), where local variations in sedimentary evolution may exist (Arzmüller et al. 2006; Strauss et al. 2006). The pull-apart basin (c. 16-8 Ma) was filled by Badenian syntectonic deposition, which was blanketed by the deposition of the Sarmatian and Pannonian successions without major depositional breaks (Arzmüller et al. 2006). 


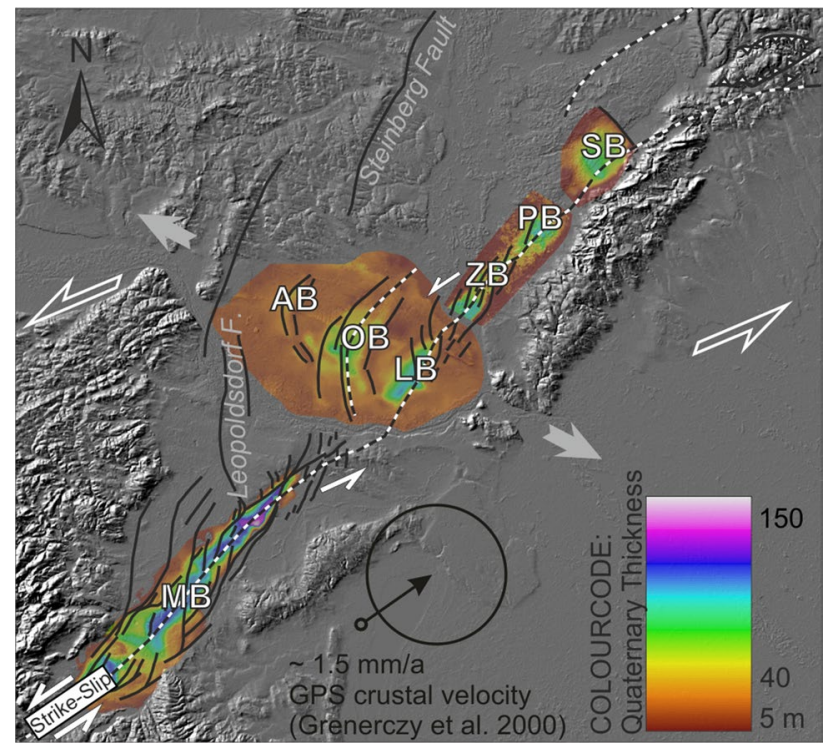

Fig. 3 Thickness data (digitized from Kullmann 1966) of Quaternary deposits draped over a shaded digital elevation model of the Vienna Basin, with tectonic sketch summarizing active kinematics and geometrical fault segmentation of the Vienna Basin strike-slip fault. MB: Mitterndorf Basin, LB: Lassee Basin, OB: Obersiebenbrunn Basin, AB: Aderklaa Basin, ZB: Zohor Basin, PB: Pernek Basin, SB: Sološnica Basin, black lines: near-surface and surface-breaking faults, white dots: strike-slip system mapped from the first-order branch lines of the associated flower structures between 3 and $5.5 \mathrm{~km}$ depth (revised from Beidinger and Decker 2011)

\section{Late Miocene-Pliocene compression and basin inversion}

In the latest Miocene, sinistral faulting and pull-apart subsidence halted during a major change of the regional stress field from $\mathrm{N}(\mathrm{NW})$-directed compression to $\mathrm{E}-\mathrm{W}$-directed compression for the Vienna Basin (Decker and Peresson 1996; Peresson and Decker 1997a, b). This phase is characterized by the gradual structural inversion with an uplift of more than $200 \mathrm{~m}$ in the Vienna Basin, which also caused sediment deformation and erosion (Decker 1996; Strauss et al. 2006). This regime is related with anomalous latestage vertical movements of the Pannonian and Carpathian region, caused by the isostatic rebound in the aftermath of continental convergence and slab detachment (Cloetingh et al. 2006; Horváth and Cloetingh 1996).

\section{Quaternary basins}

The reactivation of the Vienna Basin is related to NE-SW extension of Pleistocene basins (Fig. 3) since c. 250-300 ka (Salcher et al. 2012) at a releasing bend along the slow moving sinistral strike-slip faults (1-2 mm/year; Grenerczy et al. 2000; Decker et al. 2005). The Vienna Basin transfer fault system (VBTF) corresponds to a zone of moderate seismicity, proving the continued activity of the fault zone. These small Quaternary basins include the Mitterndorf, Aderklaa, Obersiebenbrunn, Lassee, Zohor, Pernek, and Sološnica basins (Figs. 1, 3). They are filled mainly by fluvial sediments which are unconformably overlying Miocene sediments (Kullmann 1966; Decker et al. 2005; Hinsch et al. 2005; Beidinger and Decker 2011; Salcher et al. 2012).

\section{Data}

A number of well, seismic, and geophysical data of the northern and central parts of the Vienna Basin were acquired from the archives of the Dionyz Štur Institute, Slovakia. Data of 201 wells were arranged for this study (Fig. 1) and used for sediment distribution and isopach mapping. Among them, 90 wells reaching the pre-Neogene basement were analyzed by decompaction and backstripping techniques to gain subsidence curves and rates. Missing well data in some areas were corrected by using data from the maps of the Pre-Neogene basement and the Neogene basin fill (Čekan et al. 1990; Jiříček and Seifert 1990; Wessely et al. 1993; Arzmüller et al. 2006) and interpolated from time-depth conversion of stratigraphic boundaries within seismic reflection data. These interpolated points have been termed synthetic wells. Regional water depth variations were assumed from Sauer et al. (1992) and Seifert (1992).

\section{Methodology}

The subsidence analysis uses backstripping techniques including sediment decompaction (e.g., Allen and Allen 2013). The decompaction of stratigraphic units requires the variation of porosity with depth, $\emptyset(z)=\emptyset_{0} \exp (-c z)(\varnothing$ : porosity, $z$ : depth, $\varnothing_{0}$ : initial porosity, and $c$ : coefficient) (Sclater and Christie 1980). To calculate the thickness of a sediment layer at any time in the past, it is necessary to move the layer up the appropriate porosity-depth curve (Allen and Allen 2013). Previous publications on subsidence in the Vienna Basin have mainly used empirical porosity-depth relations from literature for specific lithologies of each layer. However, for a more precise subsidence analysis, this study evaluated the on-site porosity-depth relation of the Vienna Basin based on geophysical data of two wells (Zv76 and LNV7). Seismic velocity data of the two wells were analyzed by recognizable correlations between seismic velocity-density and density-porosity. A commonly used relation between seismic velocity $\left(V_{\mathrm{p}}\right)$ and density $(\rho)$ is $\rho=a V_{\mathrm{P}}^{0.25}$ defined by Gardner et al. (1974). The relation is simply an approximate average of the relations for 
a number of sedimentary rock types. The bulk density is a function of the average density of the rock types making up the formation and the relative volumes occupied, as shown by the equation, $\rho=\rho_{\mathrm{s}}(1-\emptyset)+\rho_{\mathrm{v}} \emptyset$ where $\rho_{\mathrm{s}}$ and $\rho_{\mathrm{v}}$ are the average densities of the rock matrix and the fluid occupying the pore space (Allen and Allen 2013). From this analysis, each main stratigraphic unit of the Vienna Basin fill gained an initial porosity $\left(\emptyset_{0}\right)$ and coefficient $(c)$ (Fig. 4). The initial porosity range of 38.2-41.4\% is applicable to the clay contents $0-10$ and $60-70 \%$ in a microgeometrical model of porosity-clay content in sand-shale mixture (Marion 1990). It is fitting well to main lithology types (sandy shale and shaly sand) reported in the Vienna Basin.

Backstripping is a technique that progressively removes the sedimentary load from a basin, correcting for compaction, paleobathymetry $\left(\mathrm{W}_{\mathrm{d}}\right)$, and sea level change $\left(\Delta_{\mathrm{SL}}\right)$, in order to reveal the tectonic driving mechanisms of basin subsidence (Miall 1999). Incorporating the various effects gives the Airy compensated tectonic subsidence, $Y=S\left[\left(\rho_{\mathrm{m}}-\rho_{\mathrm{s}}\right) /\left(\rho_{\mathrm{m}}-\rho_{\mathrm{w}}\right)\right]+W_{\mathrm{d}}-\Delta_{\mathrm{SL}}\left[\rho_{\mathrm{m}} /\left(\rho_{\mathrm{m}}-\rho_{\mathrm{w}}\right)\right]$ ( $S$ : sediments thickness, $\rho_{\mathrm{w}}, \rho_{\mathrm{s}}$, and $\rho_{\mathrm{m}}$ : densities of water, mean sediment, and mantle) (Steckler and Watts 1978; Van Hinte 1978; Sclater and Christie 1980).

Because the geological data are scattered and sparse in temporal and spatial distribution, the data have to be interpolated by mapping techniques to show how they are distributed over the area (Monnet et al. 2003). Sediment isopach, subsidence rate, and depth mappings are an efficient way to understand stratigraphic context and subsidence trends of sedimentary basins. For the mapping, we arranged data to a set of 3D points based on their map location ( $x, y$ coordinates) and the sediment thickness, subsidence rate, and depth $(z)$. The arranged dataset are integrated into 2D/3D models using the MATLAB ${ }^{\circledR}$-based software BasinVis 1.0 (an open-source geological modeling software, Lee 2015; Lee et al. 2016). The smooth and interpolated surfaces are reconstructed by thin-plate spline (TPS) supported by the software, and the interpolation technique was performed in an approximately $35 \times 62 \mathrm{~km}$ study area (Fig. 1). The reconstructed surface can be viewed as partly fuzzy and non-complete model smoothing over faults, because the chosen method cannot integrate the displacement and timing of faults completely (Lee 2015; Lee et al. 2016).

In order to enhance the understanding of the regional subsidences, the tectonic subsidence trends resulted in this study were compared with the previous works conducted in the Austrian part (Hölzel et al. 2008; Lankreijer et al. 1995); the southern part of the central Vienna Basin (Fig. 5); and the southern part (Fig. 14). The previous works have a few minor differences in methodological details, compared to this study. They used largely the same Central Paratethys chronostratigraphy, and the local zones

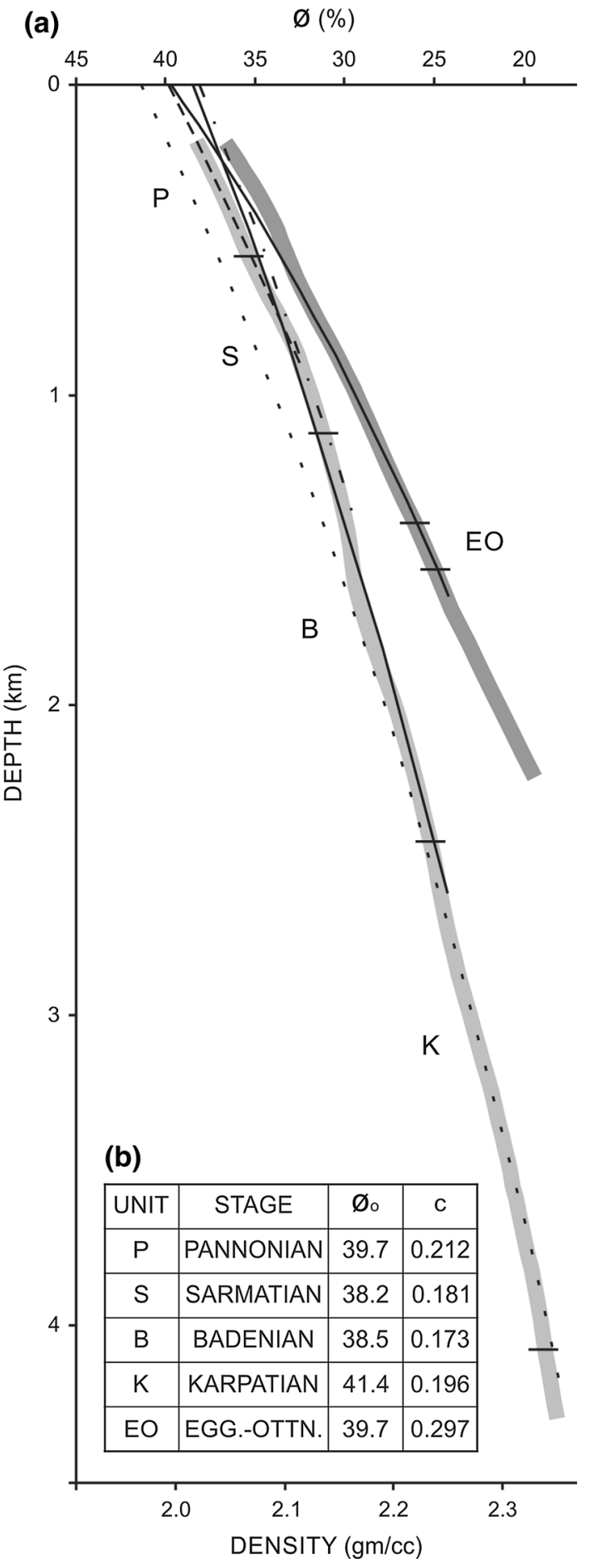

Fig. 4 Porosity-depth relation evaluated from two wells (Zv76 and LNV7) for the Vienna Basin. a Porosity and density-depth curves with exponential trend lines of each stage, $\mathbf{b}$ evaluated initial porosity $\left(\varnothing_{0}\right)$ and coefficient $(c)$ of each stage

refined since 1990s but did not include recent age refinements (e.g., Hohenegger et al. 2014). Hölzel et al. (2008) focused on the pull-apart evolution and thus analyzed subsidence from the Badenian Lower Lagenid Zone and 


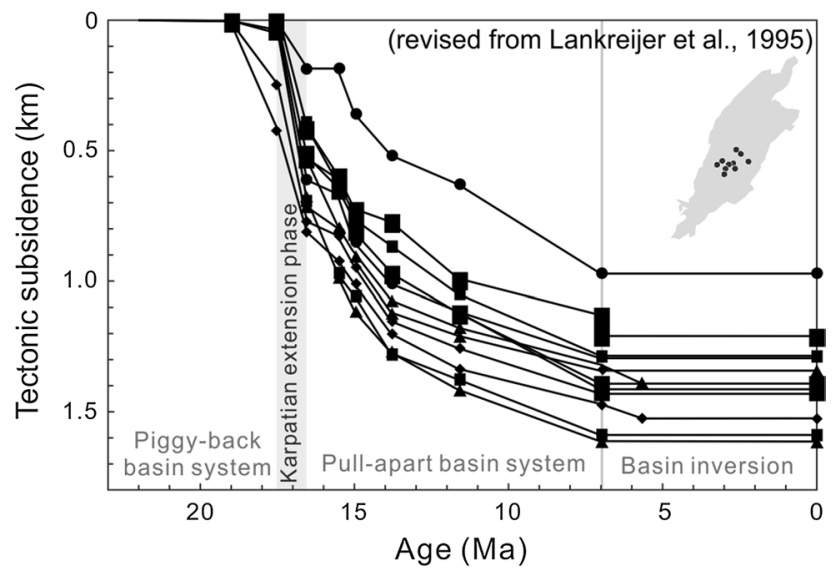

Fig. 5 Tectonic subsidence history for the Austrian part (the southern part of the central Vienna Basin) (revised from Lankreijer et al. 1995)

excluded compaction effects of the Lower Miocene sediment. And they also used empirical depth-porosity relation from literature for specific lithologies of each layer. The compacted depth and the time factor are the most influential parameters in subsidence analysis and can cause different amount and timing of subsidence rates between studies.
However, their work is still valuable for comparing overall and regional subsidence trends.

\section{Sediment distribution and isopach mapping}

Sediments of Eggenburgian to early Karpatian age (Early Miocene) are disconformably overlying the eroded surface of various Alpine-Carpathian tectonic units (Fig. 6) and are restricted to small depressions (Fig. 7a, b) in the northern and central Vienna Basin. The depressions are distributed E-W/NE-SW trending along the synsedimentary faults by the N/NW moving Alpine thrust belt and are classified as piggyback basins (Fodor 1995; Decker 1996). The Luzice Formation of the Eggenburgian-Ottnangian is gradually spreading from the depocenters in the northern part and represents various marine depositional environments (Kováč et al. 2004). The sediments recorded in the southwestern part of the study area (Fig. 7a) are correlated with the terrigenous fluvial Bockfliess Formation continuing in the Austrian part of the Vienna Basin. The Bockfliess Formation has a thickness of up to $800 \mathrm{~m}$ and was deposited until the early Karpatian (Jiř́ček and Seifert 1990; Kováč et al. 2004). The lower Karpatian sediments are thicker (up

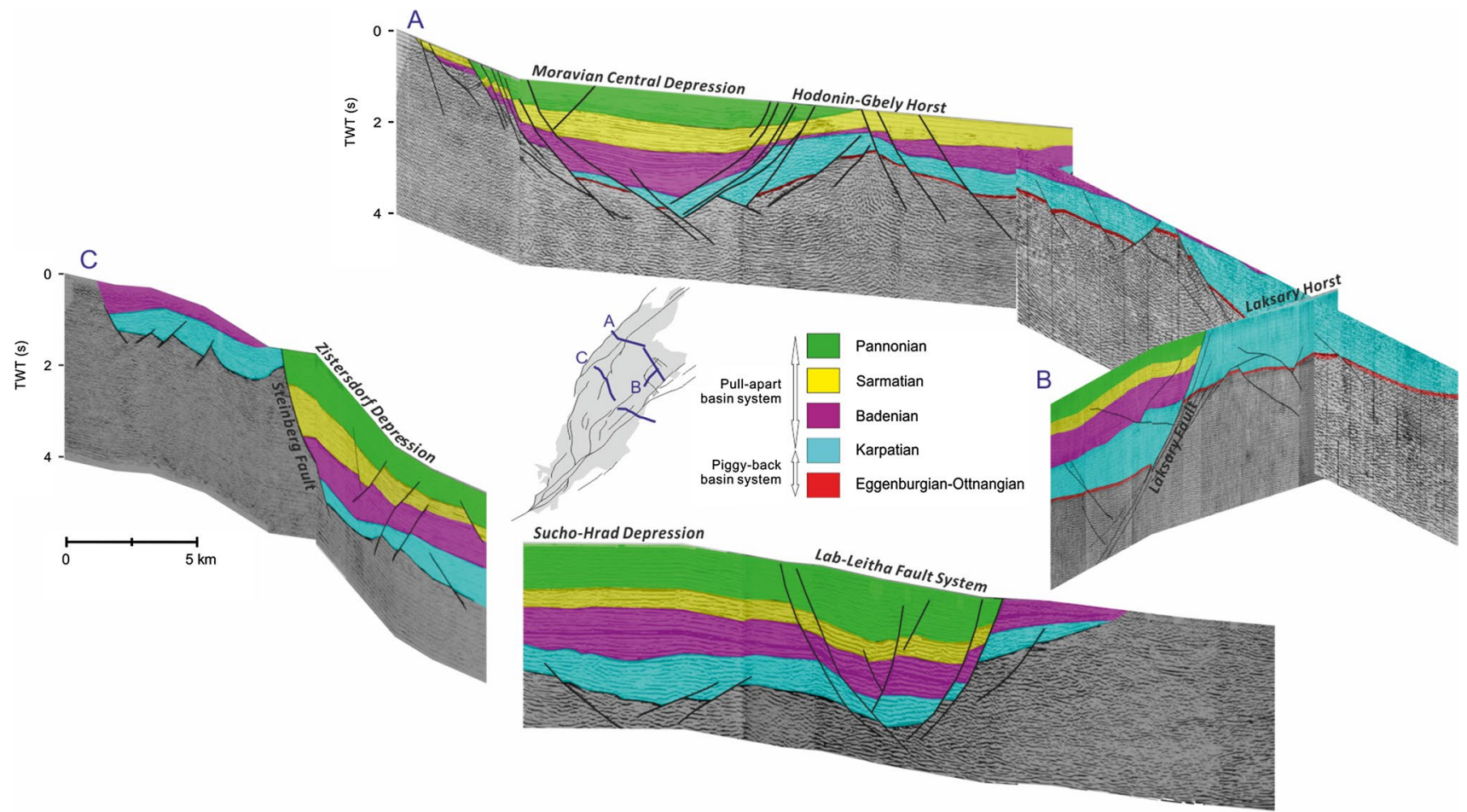

Fig. 6 Seismic sections across the study area (see Fig. 1b for location). Section $A$ and Section $C$ were revised from Čekan et al. (1990), and section $B$ was acquired from the archives of the Dionyz Štur
Institute, Slovakia. These sections were modeled by Blender which is an open-source 3D computer graphics software 

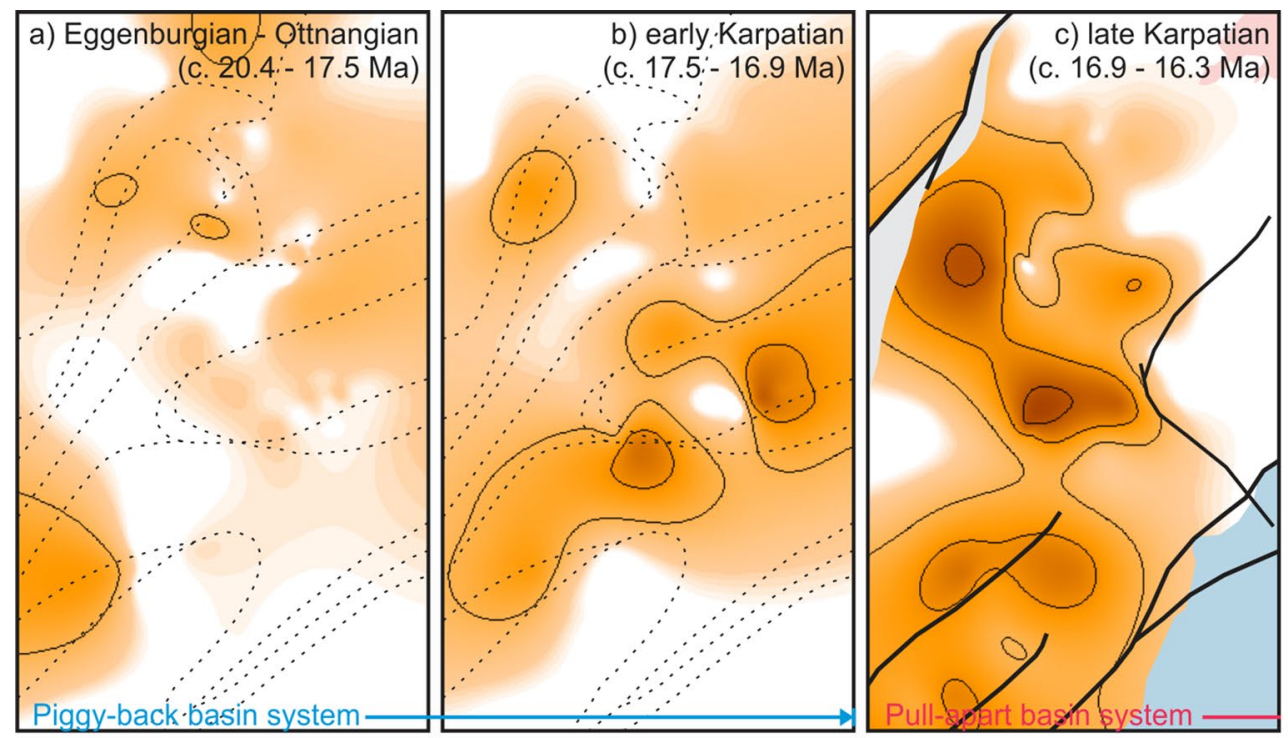

\section{SEDIMENT \\ DISTRIBUTION \\ AND \\ ISOPACH MAPPING}
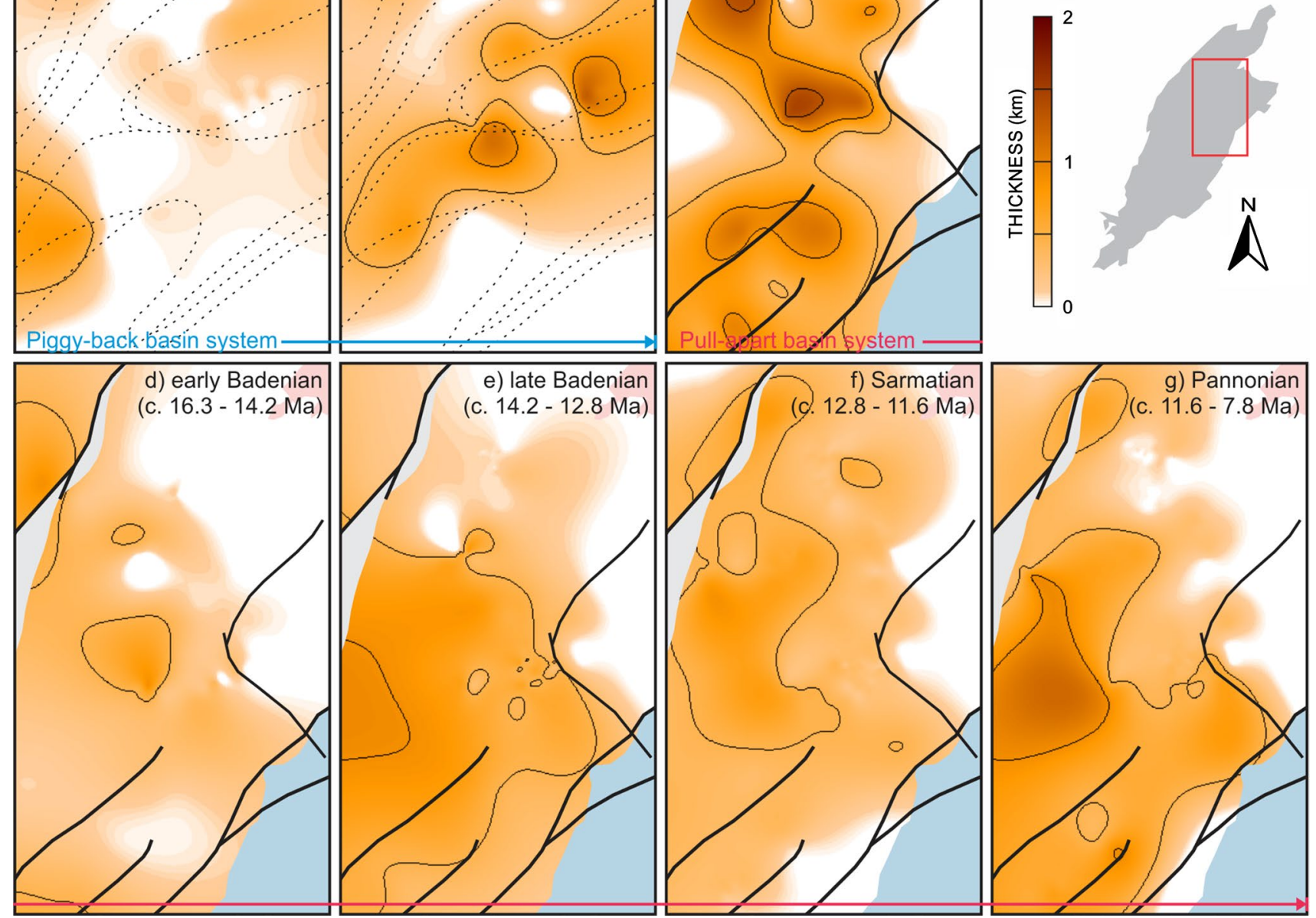

Fig. 7 Sediment distribution and isopach maps of each stage; a Eggenburgian-Ottnangian (c. 20.4-17.5 Ma), b early Karpatian (c. 17.5-16.9 Ma), c late Karpatian (c. 16.9-16.3 Ma), d early Badenian (c. 16.3-14.2 Ma), e late Badenian (c. 14.2-12.8 Ma), f Sarmatian (c.

to $1000 \mathrm{~m}$ ) and more evident NE-SW trending depocenters than the older ones (Fig. 7b).

During the late Karpatian, tectonic kinematics changed from a piggyback basin to a pull-apart basin (Fodor 1995; Decker and Peresson 1996; Hinsch et al. 2005), and the area of sedimentation widened far to the south (Fig. 7c). Nearly, the whole area of today's Vienna Basin was covered with sediments and was bordered by newly formed synsedimentary faults (Jiříček and Tomek 1981; Jiříček and Seifert 1990; Fodor 1995). The major depocenters were located between the Steinberg fault and the Laksary fault and along the Láb-Leitha fault system which consists of strike-slip faults and negative flower structures activated

12.8-11.6 Ma), and g Pannonian (c. 11.6-7.8 Ma). The Alpine-Carpathian nappe borders are shown with dotted lines for $\mathbf{a}, \mathbf{b}$, and major faults (Steinberg fault, Laksary fault, and Láb-Leitha fault system) with black solid lines for $\mathbf{c}-\mathbf{g}$

along the southeastern margin of the basin (Kováč et al. 2004) (Fig. 6). There was no sedimentation on the northern edge rim and the Laksary horst in the study area. According to Jiř́iček and Seifert (1990), Baráth et al. (2003), Kováč et al. (2004), and Arzmüller et al. (2006), the northern and northeastern margins are distinctly erosive and lack preserved marginal facies by a period of nearly total regression occurred in the Vienna Basin. Due to the regression, considerable thickness of the upper Karpatian sediments is missing in the northeastern part of the basin.

During the Badenian, the Vienna Basin was dissected into several fault blocks, resulting in lower lying strongly subsiding depocenters, and higher and more stable horst 
blocks. The faults are related to growth strata (Fig. 6). The lower to middle Badenian sediments transgressed unconformably on various layers of the Lower Miocene and the flysch substratum in the northern area (Hamilton et al. 2000) and the sedimentation reached most of the central part (Fig. 7d). The upper Badenian sediments were distributed more widely and thicker than the lower and middle Badenian ones (Fig. 7e).

Although the Sarmatian began by regression of the sea (Fig. 2), the deposition blanketed the Badenian sequences without major depositional breaks (Fig. 6). The Sarmatian sediments covered a large part of study area with the total thickness generally varying between 200 and $600 \mathrm{~m}$, and a tectonically controlled depocenter is found along the Steinberg fault (Fig. 7f).

Sedimentation during Pannonian time shows considerable similarities to the Sarmatian one. However, the depocenter in the study area was wider and deeper along the Steinberg fault and shifted slightly to the southwest (Fig. 7g). Considering uplift and erosion during the latest Pannonian and Pliocene, the Pannonian sediments would be thicker than the present-day preserved thickness.

\section{Subsidence analysis}

About 90 wells reaching the pre-Neogene basement have been investigated and sorted into ten groups. The sorting of wells was based on their position regarding fault blocks, and the positions of wells and groups are indicated in Figs. 1c and 8a. The ten groups were named after their position and blocks. Four groups in the northern part are $\mathrm{N}$ (north) $1-4$, and four groups in the central part are $\mathrm{C}($ Center $) 1-4$. Two groups situated at basement highs are L1-2, which follow the first letter of their block names (Lužice and Lakšárska Nová Ves).

Subsidence curves and rates of selected wells are presented in this study. The model graph shows how the results are presented for subsidence history of each group (Fig. 8b). The graphs represent the basement subsidence curves with dashed lines and the tectonic subsidence curves and rates with solid lines.

\section{Subsidence trend and axes of the northern part}

Wells of N1-4 are located in the northern Vienna Basin (Fig. 1b). The common trend is the stepwise subsidence patterns of the basement subsidence with two increasing stages and of the tectonic subsidence with one increasing stage. Total subsided depths of each group are deepening from N1 to N4 approaching to the central part of the Vienna Basin (Fig. 9). (a)

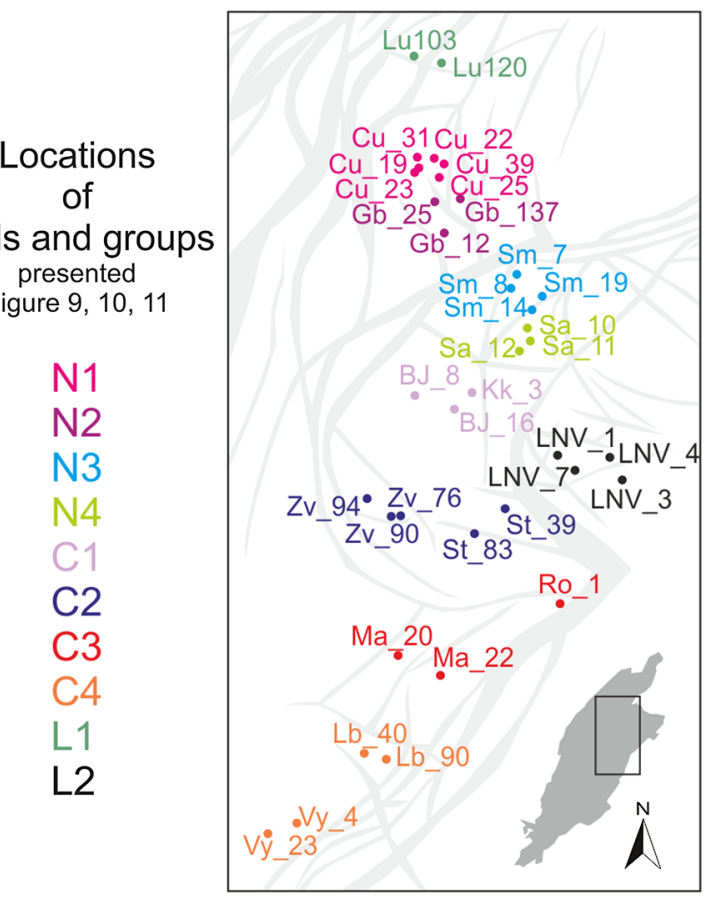

(b)

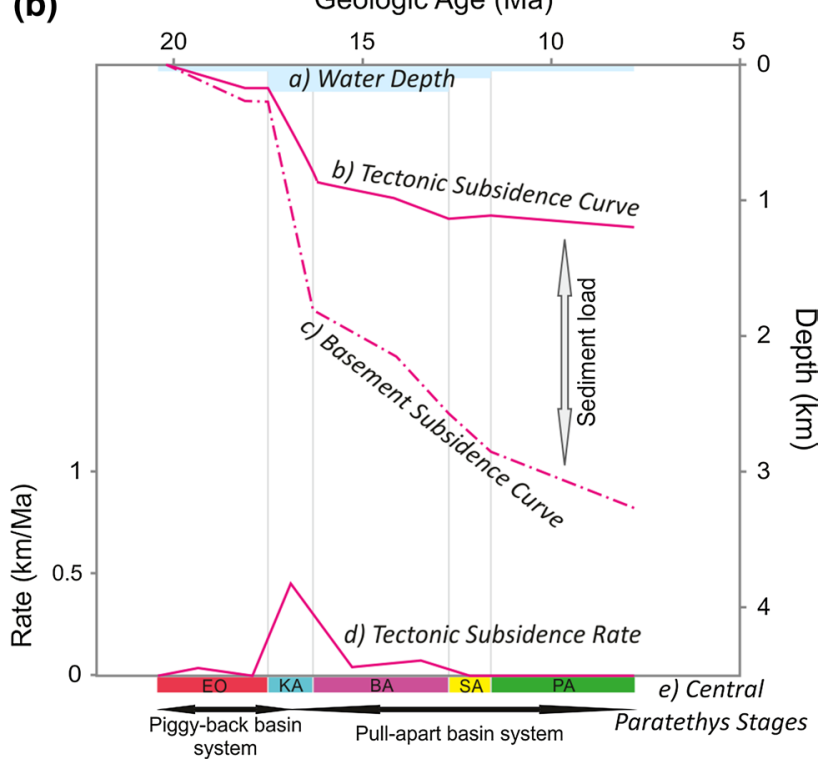

Fig. 8 a Locations of wells and groups presented in Fig. 9, 10, and 11 (N1-4, Cl-4, and L1-2). b Model of subsidence graphs in this study; $a$ assumed average water depth (Sauer et al. 1992; Seifert 1996), $b$ tectonic subsidence curve (solid line), $c$ basement subsidence curve (dashed line), $d$ tectonic subsidence rate (solid line), and $e$ Central Paratethys stages; EO: Eggenburgian-Ottnangian, KA: Karpatian, BA: Badenian, SA: Sarmatian, and PA: Pannonian

The subsidence of N1-4 started during the Eggenburgian-Ottnangian. It was rather slow and showed basement subsidence of up to $300 \mathrm{~m}$. This minor subsidence aligned along the thrusts is indicating the main piggyback basin phase. 

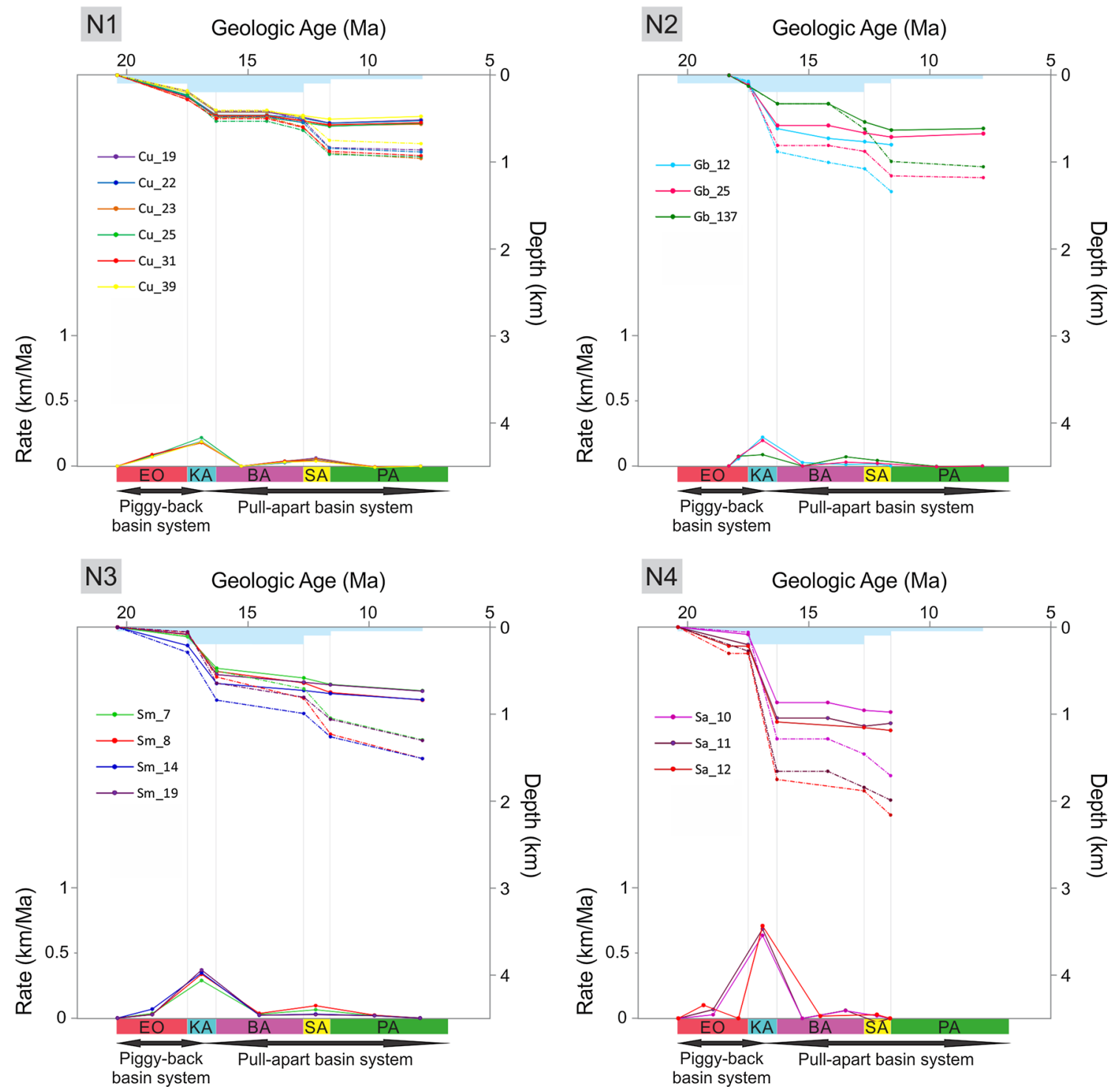

Fig. 9 Subsidence curves and tectonic subsidence rates of group N1-4

For Karpatian times, the subsidence curves document a rapid increase in both basement and tectonic subsidences (Fig. 9). The Karpatian data of wells in this group were not separated precisely between the lower and upper stages, and this made it hard to compare subsidence rates between the early and late Karpatian. In the northern part, the lower Karpatian sediments were thinner than the upper ones (Jiříček and Seifert 1990) (Fig. 7b, c). Therefore, the recorded increasing Karpatian subsidence is interpreted as a combination of minor piggyback and major pull-apart tectonics.

For the Badenian, tectonic subsidence was low and almost stationary with few notable changes (Fig. 9). During the early Badenian, wells in the northern part show only minor subsidence, because lower Badenian sediments were not reported in the region. From the late Badenian to the Sarmatian, wells of N1-4 show slightly increasing tectonic subsidence. At this time, however, the basement depth was increasing significantly without obvious tectonic effects; therefore, this high basement subsidence is interpreted as a result of significant sediment loading.

Most subsidence curves of N1-4 continued until the Pannonian; however, Gb12 in the N2 and wells in N4 stopped subsiding at the end of the Sarmatian (Fig. 9). Some wells also show decreasing tectonic subsidence during the Sarmatian-Pannonian. This study considers that this resulted from uplift and erosion by the basin inversion of the late Pannonian-Pliocene. 

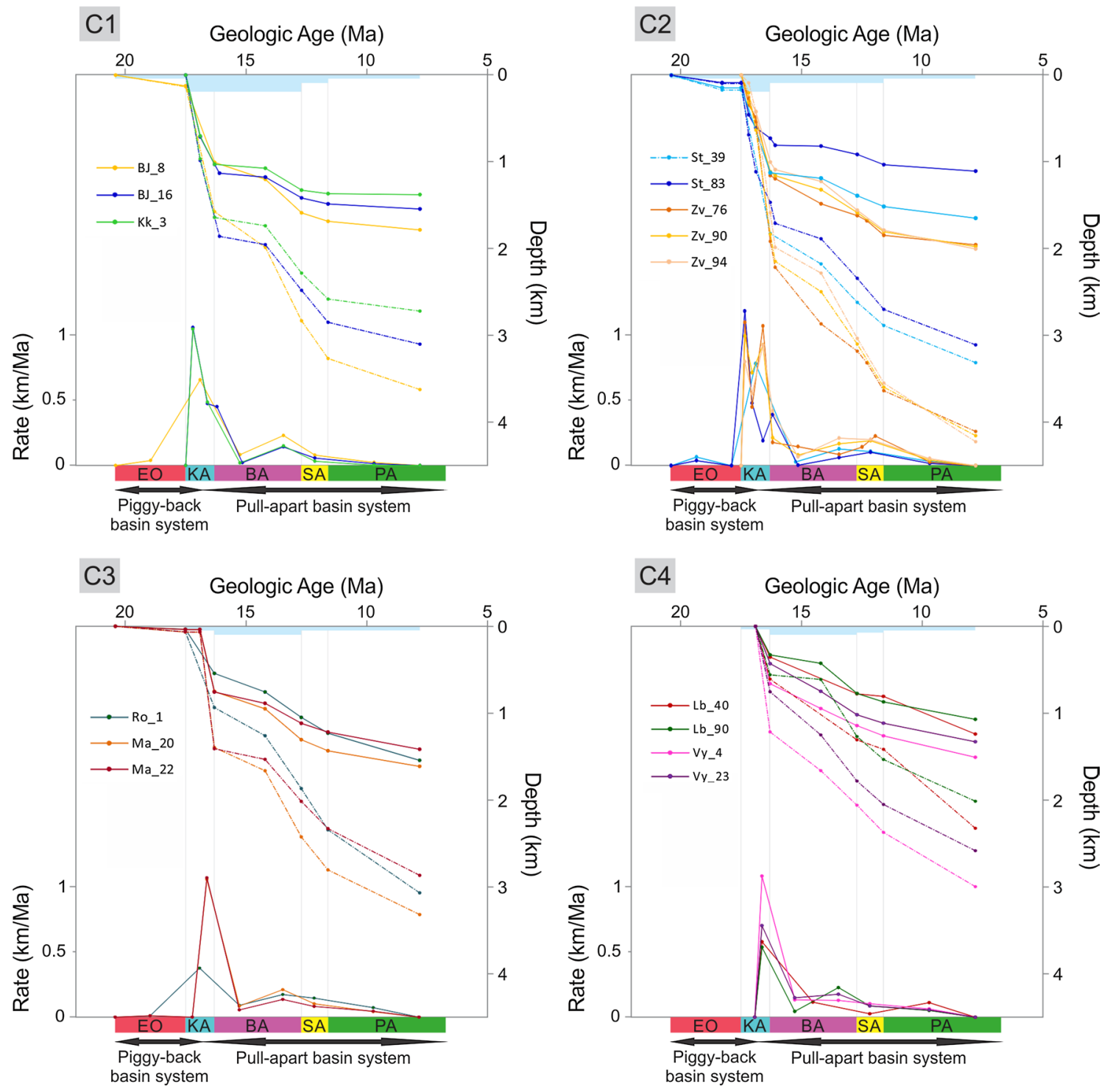

Fig. 10 Subsidence curves and tectonic subsidence rates of group $C 1-4$

\section{Subsidence trend and axes of the central part}

Groups C1-4 are located broadly in the central part of the basin and comprise data from hanging wall blocks along major faults (Fig. 1b). C1 and C2 are lying on the hanging wall between the Steinberg fault and the Laksary fault. In C2, the Závod (Zv) wells are closer to the Steinberg fault and the Studienka (St) wells are located near the Laksary fault. C3 and C4 are situated near the Láb-Leitha fault system along the southeastern border of the Vienna Basin. The subsidence patterns of this group are highly dependent on the development of the major tectonic driving faults.

Most wells of C1-3 started to subside during the piggyback basin time and exhibited quite slow subsidence with thin sediments (up to $170 \mathrm{~m}$ ) in the Eggenburgian-Ottnangian (Fig. 10). However, C4 recorded no sediments for this time and subsided only from the late Karpatian initiating the pull-apart tectonics.

In the Karpatian, all areas of $\mathrm{C} 1-4$ show abruptly increasing basement and tectonic subsidences (Fig. 10). Although some wells of $\mathrm{C} 1$ and $\mathrm{C} 2$ already subsided considerably in the early Karpatian, overall the high subsidence was dominant during the late Karpatian. Especially, the Závod wells of $\mathrm{C} 2$ near the Steinberg fault subsided almost $2 \mathrm{~km}$ during this time interval. The Karpatian subsidence was much higher here than in the northern part of the basin, due to large displacement along the Steinberg fault and other major synsedimentary faults located in the central Vienna Basin. 

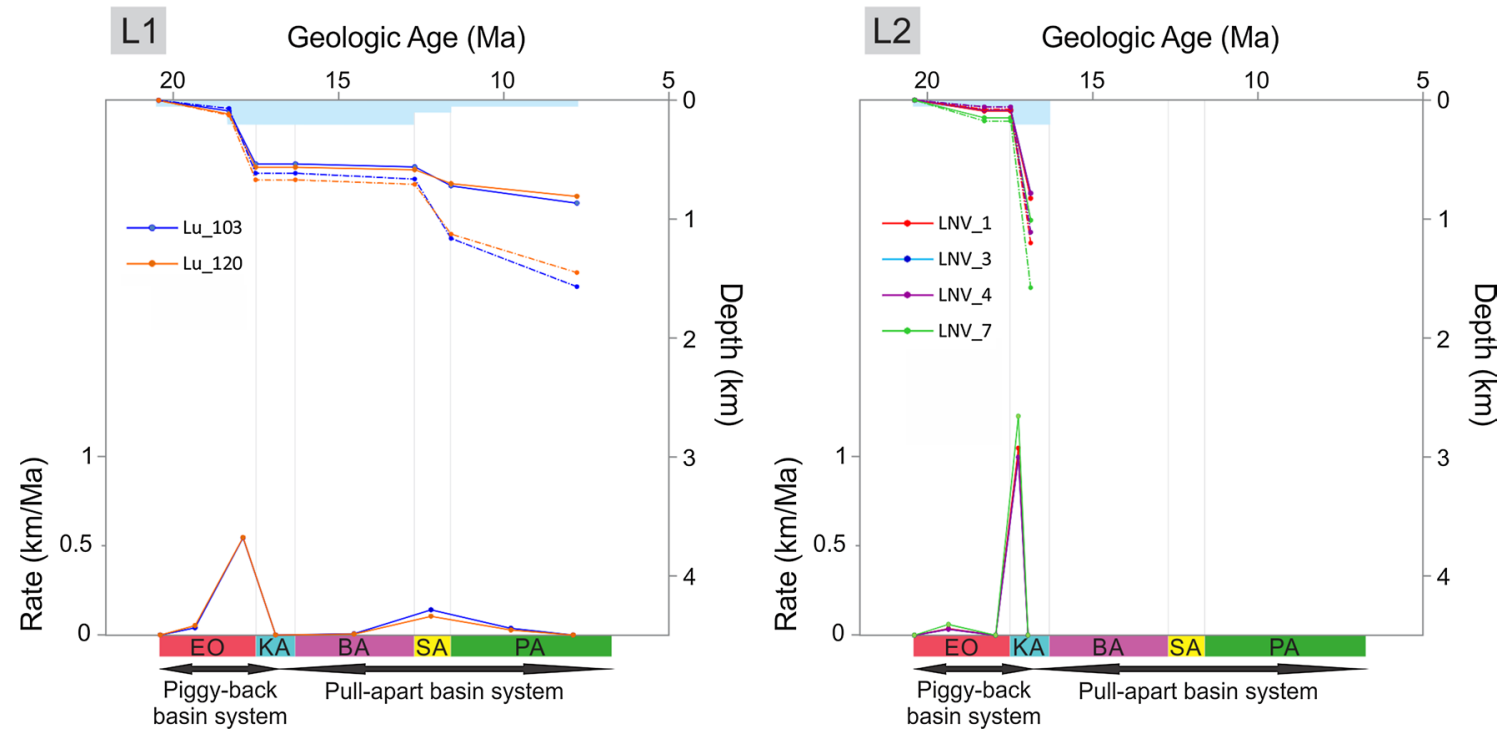

Fig. 11 Subsidence curves and tectonic subsidence rates of group $L 1-2$

After the major Karpatian subsidence pulse, $\mathrm{C} 1$ and the Studienka wells of $\mathrm{C} 2$ almost stopped subsiding with thin sedimentation during the early Badenian. However, the Závod wells of $\mathrm{C} 2$ and $\mathrm{C} 3-4$ continued the tectonic subsidence slowly during this time (Fig. 10). In the late Badenian, C1-4 show increasing tectonic subsidence more evidently than N1-4.

While $\mathrm{C} 1$ has a stationary tectonic subsidence pattern during the Sarmatian, which is similar with the northern part, C2-4 display continuous tectonic subsidence until the Pannonian (Fig. 10). With the exception of some wells of $\mathrm{C} 2$, Sarmatian and Pannonian tectonic subsidence was minor compared to the late Badenian subsidence. Since the late Badenian, the basement subsided enormously (up to $2 \mathrm{~km}$ ). However, it was mostly affected by sediment loading, not much by tectonic effects as shown by only minor tectonic subsidence.

\section{Subsidence trend and axes of the basement highs}

The groups L1 and L2 are located each in the northern basement high and the Laksary horst (Fig. 1b). The subsidence curves of L1-2 show strong differences compared to the subsidence patterns of the other groups in this study.

After the slow subsidence of the Eggenburgian-Ottnangian, L1 had no significant Karpatian and Badenian subsidences at all and L2 had subsided until the early Karpatian (Fig. 11). This may be due to the fact that L1-2 areas subsided mainly during the piggyback phase time (although by some reasons group L1 subsided again from the Sarmatian).
The late Karpatian is a highly important time in the Vienna Basin, because the structural type of the basin changed from piggyback to the pull-apart basin by onset of transtensional tectonic movement. However, the late Karpatian and subsequent Badenian sediments are not found in the areas of L1-2. This supports the idea that the areas of L1-2 were not affected by these transtensional tectonics and, in contrast to most parts of the basin, underwent transpressional stress during the time. According to Jiříček and Tomek (1981) and Fodor (1995), in the Badenian, depocenters and subsidence moved to the south, and a significant angular discordance in the northern sedimentation area indicates uplift and deformation. The basin inversion was due to local transpressional tectonics where sinistral slip transferred toward the northeast.

\section{Tectonic subsidence rate mapping}

Tectonic subsidence shows the idealized subsidence history of a basin that would have existed if only water, and no sediment, filled the subsiding depression. This enables the evaluation and classification of the general tectonic driving force for subsidence at different positions within a single basin (Xie and Heller 2009; Allen and Allen 2013). To understand regional tectonic trends in the study area, the tectonic subsidence rates were interpolated in Fig. 12 for each major stratigraphic units.

During the piggyback basin time, the subsidence from the Eggenburgian to the Ottnangian was slowly subsiding in $\mathrm{E}-\mathrm{W}$ trending depressions (Fig. 12a), while the early Karpatian basin setting was deeper and more NE-SW trending (Fig. 12b). The NE-SW trending strike, however, 

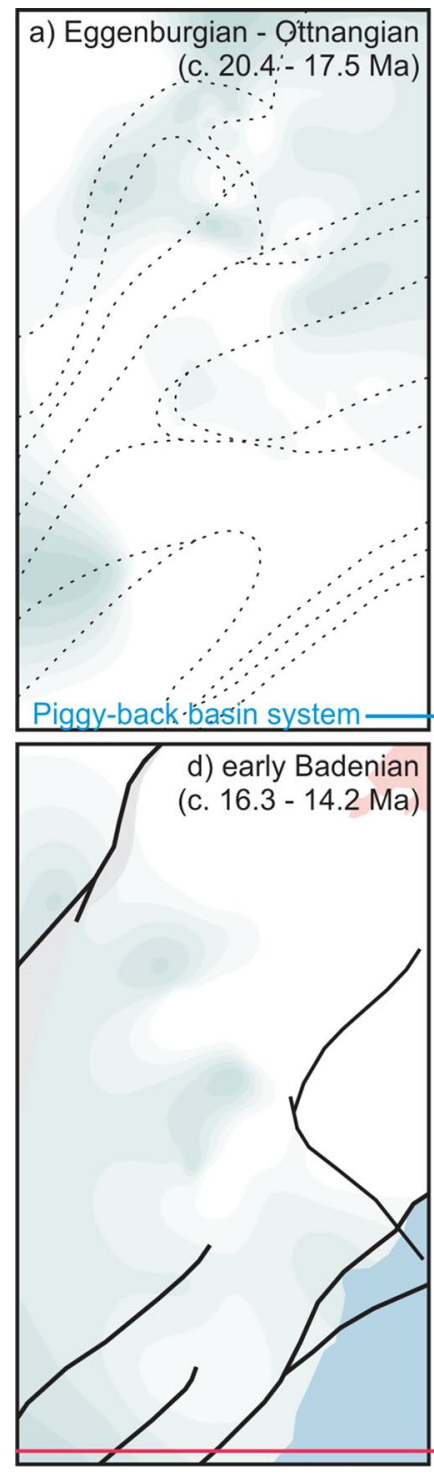

d) early Badenian

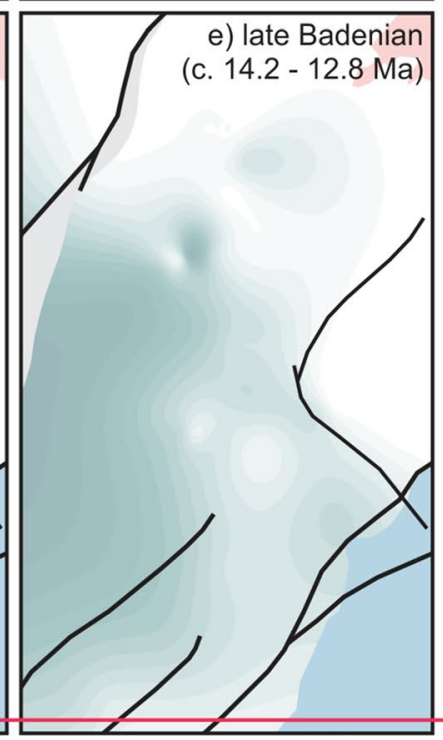

Fig. 12 Maps of tectonic subsidence rate of each stage; a Eggenburgian-Ottnangian (c. 20.4-17.5 Ma), b early Karpatian (c. 17.516.9 Ma), c late Karpatian (c. 16.9-16.3 Ma), d early Badenian (c.

is not genetically related to the Láb-Leitha strike-slip fault system. This can be related to an apparent counterclockwise rotation of the Alpine thrust front between the Eggenburgian and the Karpatian (Beidinger and Decker 2014), resulted from the eastward increase of the cumulative insequence thrust distance.

During the late Karpatian, the tectonic subsidence rate and pattern changed abruptly (Fig. 12c) as a result of the principal change in the basin type. The tectonic subsidence rate increased rapidly over the area except for the northern basement high and the Laksary horst. This increase is strongly related to movement along the NE-SW trending strike-slip and normal faults. The faulted areas subsided considerably, especially in the hanging wall of the

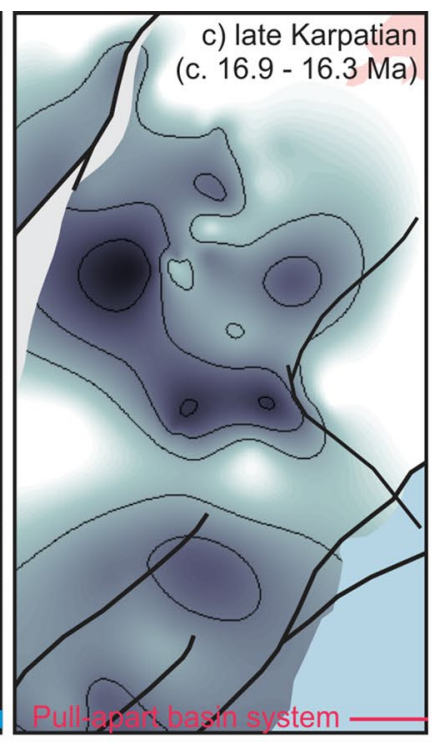

\section{TECTONIC \\ SUBSIDENCE RATE MAPPING}
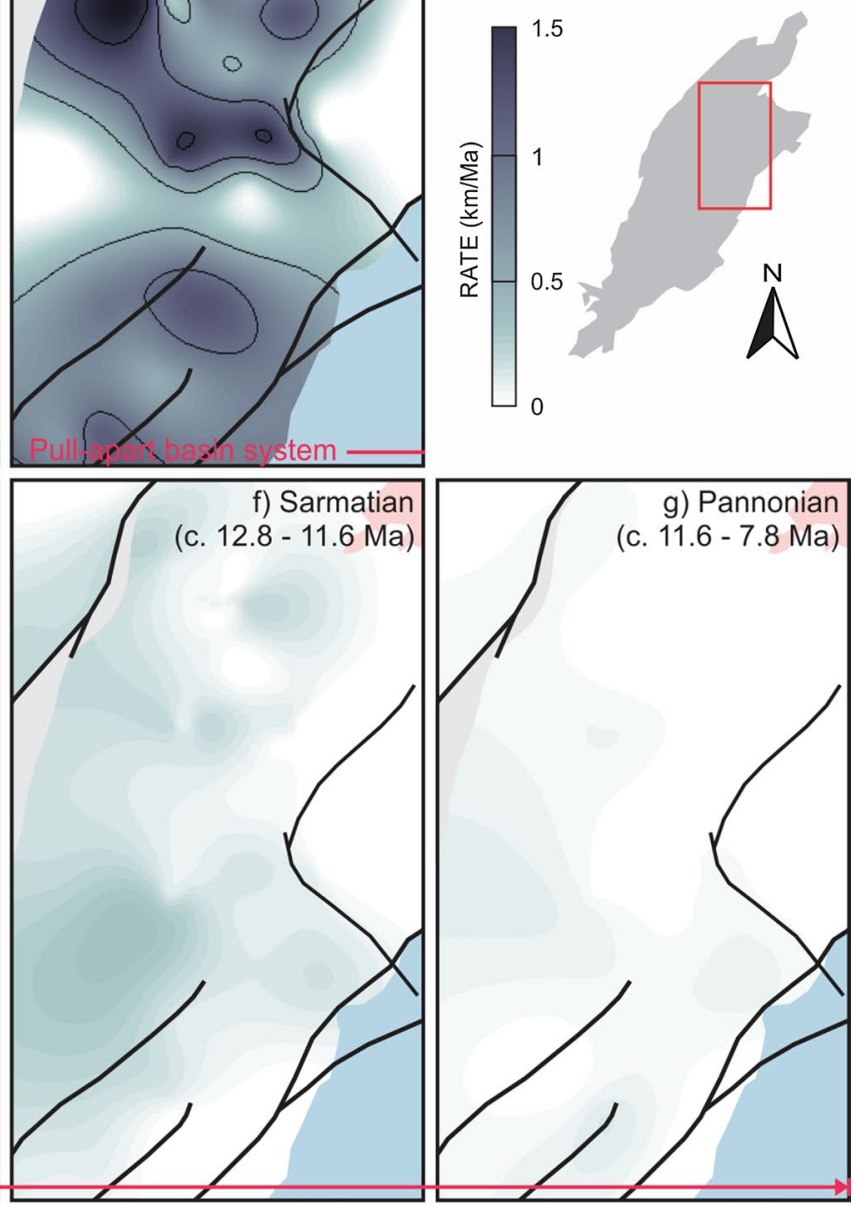

16.3-14.2 Ma), e late Badenian (c. 14.2-12.8 Ma), f Sarmatian (c. 12.8-11.6 Ma), and g Pannonian (c. 11.6-7.8 Ma)

Steinberg fault and along the negative flower structure of the Láb-Leitha fault system.

After this large-scale subsidence phase, the tectonic subsidence rate decreases markedly in the early Badenian (Fig. 12d). Rates decreased to zero abruptly in the northern part, whereas the central part is characterized by ongoing slower tectonic subsidence. These slow subsidence rates increased again during the late Badenian along the Steinberg fault, and the central part including the Spannberg ridge subsided widely (Fig. 12e).

During the Sarmatian, the tectonic subsidence continued and its subsiding area spread to the north along the Steinberg fault (Fig. 12f). The tectonic subsidence rate decreased again in the Pannonian, remaining weak subsidence near 


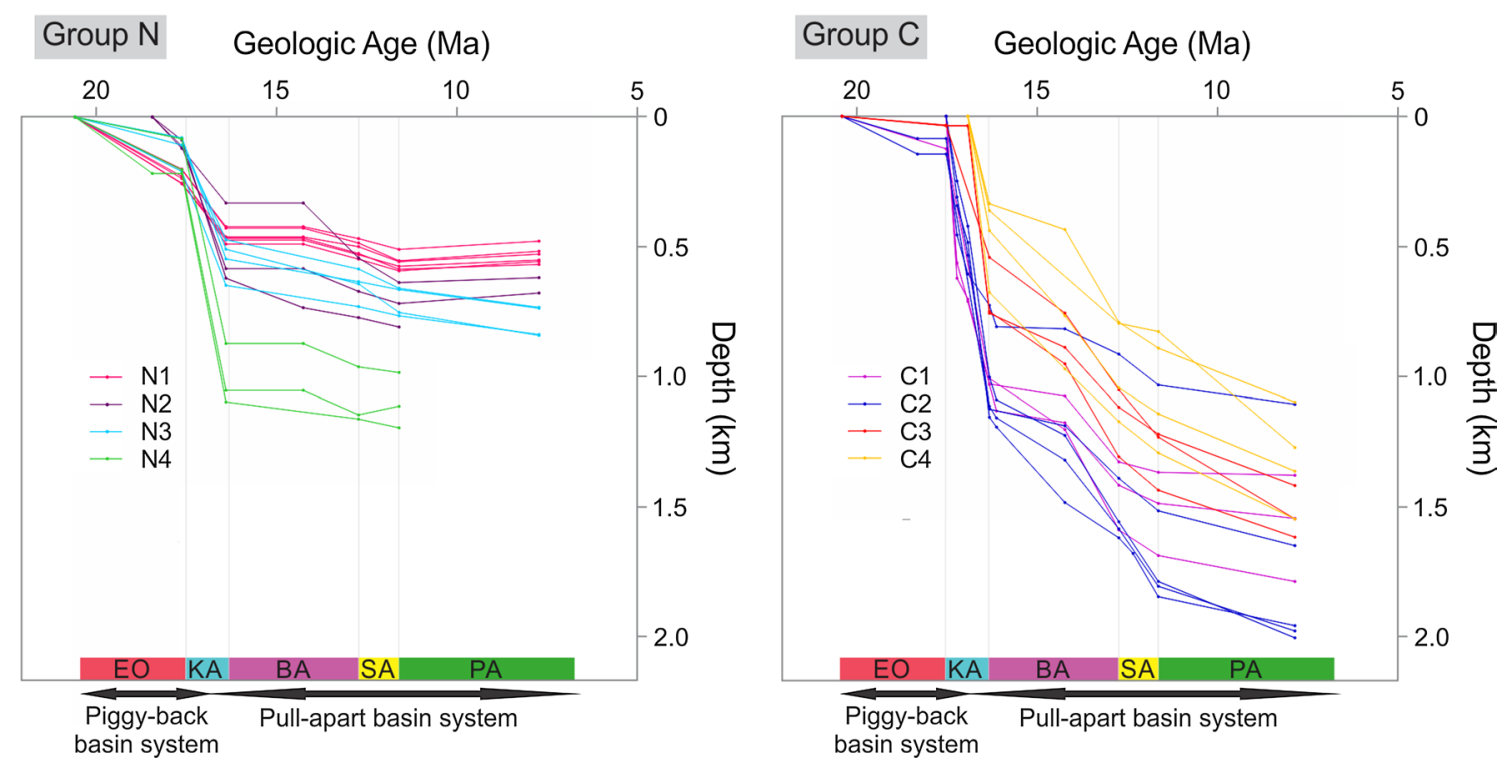

Fig. 13 Tectonic subsidence curves of the northern part $(\mathrm{Nl}-4)$ and the central part $(\mathrm{Cl}-4)$

Fig. 14 Tectonic subsidence rates of the northern, central, and southern parts of the Vienna Basin. Rates of the southern part are taken from Hölzel et al. (2008). The tectonic subsidence rates of the Quaternary basins were calculated from thickness data presented in Fig. 3

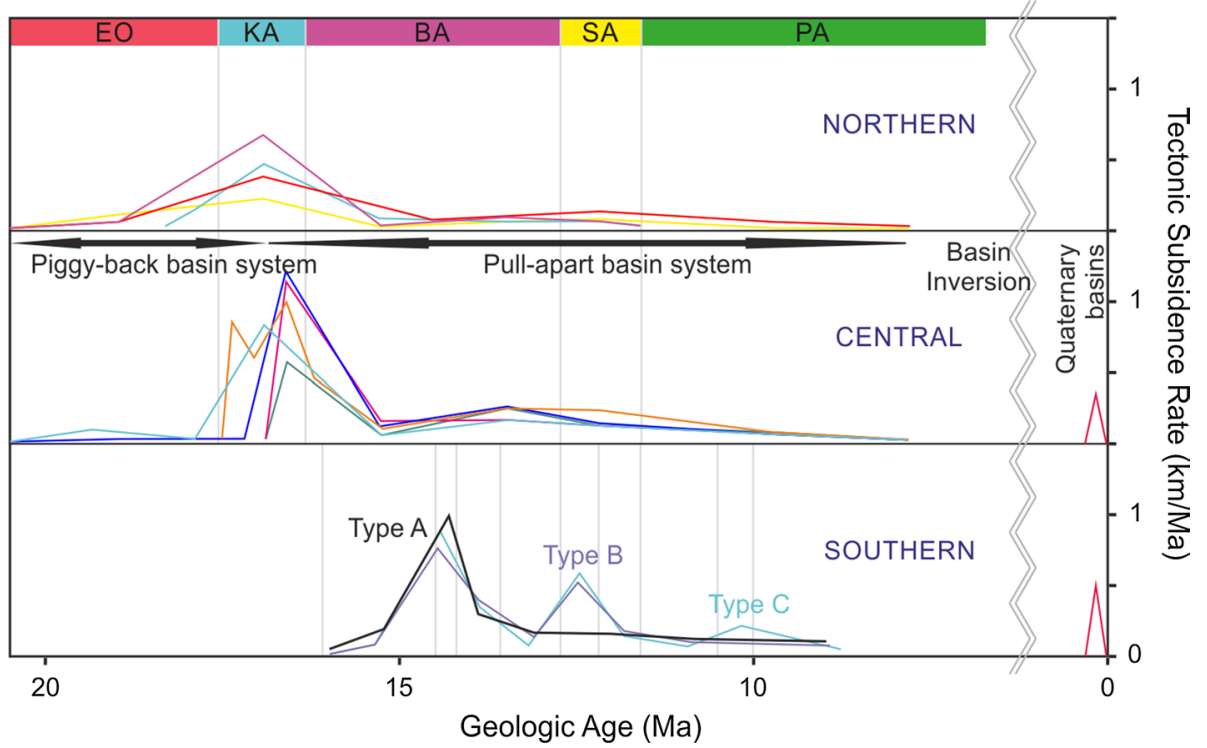

\section{Quaternary basin subsidence}

sidence corresponds to the axis of $\mathrm{E}-\mathrm{W}$ trending extension found in the western parts of the Pannonian Basin system for the late Sarmatian-early Pannonian (Huismans et al. 2001). The changing tectonic regime is supported by that the transpressional area (the northern basement high; group L1) subsided again from the Sarmatian onwards (Fig. 11). Similar extension is also reported in neighboring basinsthe Styrian Basin and the Danube Basin (Vass et al. 1990; Sachsenhofer et al. 1997; Kováč et al. 1999).
The small Quaternary basins are filled mainly by fluvial sediments up to $150 \mathrm{~m}$ thick along the Vienna Basin transfer fault (Fig. 3). Using the Quaternary sediment thickness data, this study calculated the tectonic subsidence rates of the Quaternary basins (Fig. 14). The Mitterndorf Basin located in the southern part has a tectonic subsidence rate of $\sim 0.5 \mathrm{~km} / \mathrm{Ma}$, and other basins in the central part have the rate of $\sim 0.3 \mathrm{~km} / \mathrm{Ma}$. 


\section{Discussion}

The tectonic subsidence of strike-slip basins is mainly episodic, short lived (typically $<10 \mathrm{Ma}$ ), and end abruptly with commonly very high tectonic subsidence rates $(>0.5 \mathrm{~km} /$ Ma) compared to all other basin types (Cloetingh et al. 1992, 1996; Xie and Heller 2009; Allen and Allen 2013). The high tectonic subsidence rates of the late Karpatian time in the Vienna Basin, which was caused by the evolution of the master strike-slip faults, occurred in only short time of $c$. 0.6 Ma. The tectonic subsidence curves reflect generally the typical 'concave-up' shape pattern displayed in basins in strike-slip zones (Fig. 13).

After the strong subsidence phase, this study found that the tectonic subsidence nearly stops in the northern part, whereas the central and southern parts are characterized by a gradually decreasing pattern (Figs. 13, 14). The significant subsidence difference between the parts during the Middle Miocene was recorded already in previous works (Royden 1985; Lankreijer et al. 1995). There were two major suggestions to explain the different subsidence decrease patterns observed in the Vienna Basin.

Royden (1985) interpreted the Vienna Basin as a typical example of how thin-skinned extension can create a sedimentary basin. The work stated that post-extensional (or thermal) subsidence within the basin is impossible, because the extension and the associated strike-slip faulting were restricted to shallow levels, and thus, no significant gradually decreasing thermal subsidence phase is present. Royden (1985) analyzed subsidence curves of the basin for two different cases: (1) for the northeastern part, where most of the subsidence and sedimentation is of Early Miocene age or older, and (2) for the south-central part, where most of the subsidence is of the Middle to Late Miocene age. The study, however, analyzed uncorrected subsidence curves neglecting compaction of sediments and failed to explain tectonically why subsidence happened locally in different times.

The other model by Lankreijer et al. (1995) proposed a post-rift (thermal) subsidence for the central part. According to these authors, the Vienna Basin comprises a non-uniform extensional basin changing from thin-skinned extension in the northern part to whole lithospheric extension in the central part. However, there is no major thermal anomaly arguing for backing up the lithospheric extension and the heat flow is uniformly low in the basin (Dövényi and Horváth 1988; Sachsenhofer 2001). Additionally, in such a small size basin, the coexistence of two extension types seems highly speculative. Lankreijer et al. (1995) also suggested that the deep-rooted strike-slip and normal faults reactivated preexisting fault planes (Wessely 1988; Picha 1996) which penetrated locally into the overlying thrust belt and created a new structural regime (e.g., Sanchez et al. 2015). However, there is no strong evidences yet that the major faults in the southern and central parts are connected to preexisting fault planes.

In details of the Badenian (Middle Miocene) subsidence, the high rate of the Upper Ladenid Zone observed in the southern part is missing in the rest of the Vienna Basin, and in the central and northern parts, the late Badenian subsidence rate is higher than the early Badenian (Upper Ladenid Zone) one (Fig. 14). Hölzel et al. (2008) explained this differential subsidence mainly with a paleoenvironmental effect caused by the Spannberg ridge which was uplifted at the end of the Karpatian (Hölzel et al. 2010). The ridge largely restricted sedimentation in the southern part during the Early Miocene. Consequently, only non-marine sediments are known from the southern part of the Vienna Basin during this time interval (e.g., Seifert 1996). Subsequently, the ridge was buried in the late Badenian and caused sedimentation to spread to the central part.

This study, however, supports that the regional difference of the Badenian tectonic subsidence was caused by a Badenian paleostress change. The differential Badenian tectonic subsidence observed in this study is more in accordance to Weissenbäck (1996), who showed that the synsedimentary fault activity in the basin displays a time-transgressive trend from south to north during that time. According to Fodor (1995), the Middle Miocene evolution was characterized by a combination of strikeslip (transtension) and extensional faulting rather than a pure strike-slip or pure tensional regime. Therefore, the differential subsidence can be related to the changing tensional regime of weakening transtension and strengthening extension toward the late Middle Miocene. This also means the major fault activity successively advanced toward north (from the strike-slip fault system in the south to the Steinberg fault) during the Badenian. This study supposes that the Middle Miocene tensional regime also partly caused the different tectonic subsidence trend between the northern and other parts (Figs. 13, 14). Although the Middle Miocene tectonic subsidence of the northern part is very weak, the tectonic subsidence increasing from the late Badenian, observed in N1, 2, and 4 , is fairly corresponding to the tectonic subsidence pattern of the central part. The different subsidence amount can be connected to the location of the major driving faults of the Vienna Basin. The faults evolved mainly during the late Karpatian are found mostly in the central and southern parts (Fig. 1b). The tensional activities of the Eastern Alps and the Pannonian Basin system caused the stronger tectonic subsidence in the central and southern parts.

The Sarmatian-Pannonian (late Middle-Late Miocene) subsidence occurred dominantly along the Steinberg fault in the northern and central parts (Fig. 15). In the southern 
Fig. 15 Maps of tectonic subsidence depth at the each major phase; a c. 20.4-16.9 Ma (Eggenburgian-early Karpatian; piggyback subsidence), b c. 16.9-16.3 Ma (late Karpatian; Transtensional subsidence), c c. 16.3-12.8 Ma (Badenian; combination of transtensional and extensional subsidence), and d c. 12.8-7.8 Ma (Sarmatian-Pannonian; extensional subsidence). Presented paleostresses were modified from Fodor (1995), Decker (1996), Peresson and Decker (1997a, b), and Hölzel et al. (2010)

part, the Bockfliess and Markgrafneusiedl faults were the major active faults in this time (Hinsch et al. 2005). The subsidence is corresponding to the axis of E-W trending extension found in the western parts (e.g., Styrian Basin and Danube Basin) of the Pannonian Basin system for the late Sarmatian-early Pannonian (Huismans et al. 2001). The Pannonian subsidence was slow and regionally restricted in the study area (Fig. 12g). However, subsidence results calculated in this study may be biased due to the fact of missing significant parts of the youngest sedimentary column. The latest Pannonian and Pliocene E-W compressional event resulted in basin inversion and sediment deformation (Decker and Peresson 1996; Peresson and Decker 1997a; Cloetingh et al. 2006). Uplift of more than $200 \mathrm{~m}$ is assumed (Strauss et al. 2006), which eroded Pannonian sediments. Therefore, it is possible that the Pannonian subsidence has been underestimated due to missing thickness data. In addition, we found that in some of our well data Quaternary deposits have not been separated from Pannonian sediments. Along the still active Vienna Basin transfer fault, the Pannonian subsidence observed in C3-4 thus also partly includes Quaternary subsidence.

\section{Conclusions}

The special position of the Vienna Basin caused that the tectonic subsidence history reflects the regional tectonic evolution of surrounding units. The central and southern parts have more distinct tectonic subsidence during the Middle-Late Miocene due to the location of the major driving faults. The tectonic subsidence history of the Vienna Basin can be arranged to five subsidence phases (Fig. 15);

1. Axis of E-W trending piggyback subsidence (Eggenburgian-early Karpatian, Early Miocene). In the Early Miocene, the piggyback basin started to subside in front of the thrusting active Alpine sheets. The subsidence was slow along an E-W trending axis, and in the early Karpatian became stronger along a NE-SW trending axis by an apparent counterclockwise rotation of the Alpine thrust front.

2. Axis of NE-SW trending transtensional subsidence (late Karpatian). High subsidence during the late Karpatian was accelerated and further enlarged mainly by

\section{TECTONIC SUBSIDENCE DEPTH MAPPING}
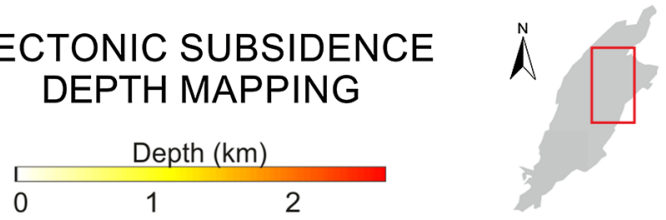

(a) c. 20.4 - 16.9 Ma (Piggy-back subsidence)

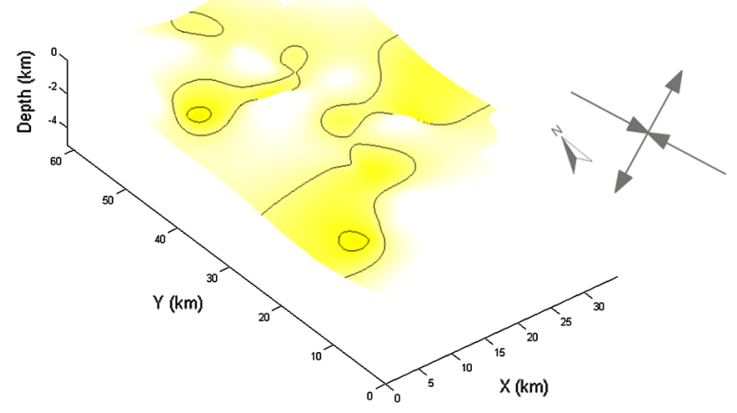

(b) c. $16.9-16.3 \mathrm{Ma}$ (Transtensional subsidence)

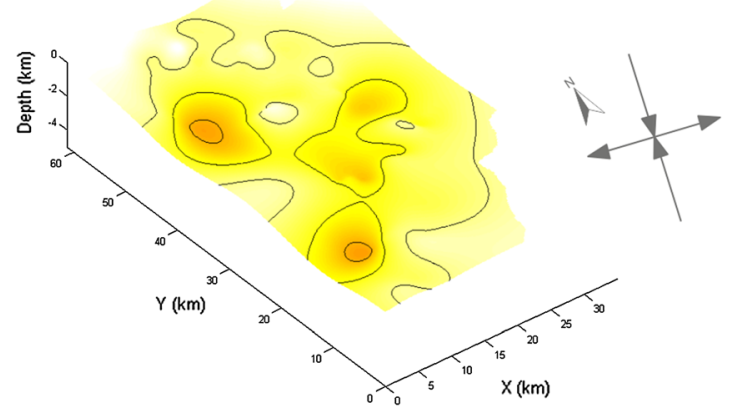

(c) c. $16.3-12.8 \mathrm{Ma}$ (Combination of Transtensional and Extensional subsidence)

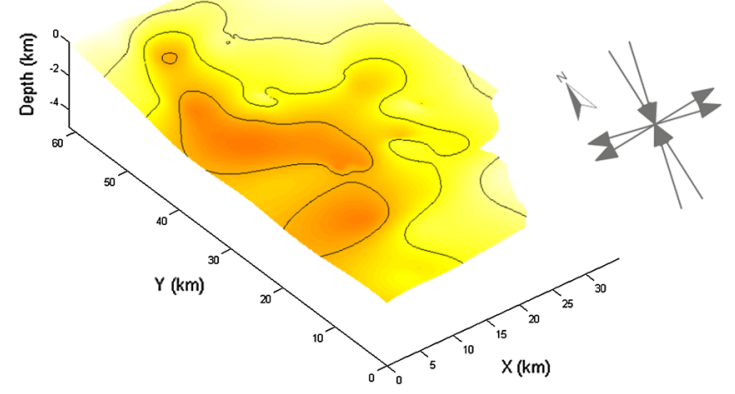

(d) c. 12.8 - 7.8 Ma (Extensional subsidence)

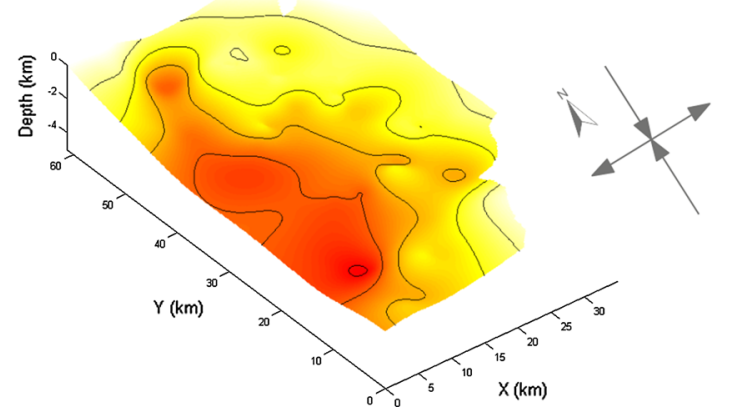


sinistral strike-slip duplexes and by listric faults connected to strike-slip faults. The transtensional subsidence affected most parts of the basin except the northern basement high and the Laksary horst which are considered as transpressional regime areas.

3. Axis of combination of transtensional and extensional subsidences (Badenian; Middle Miocene). During the Badenian, the tectonic subsidence history varies laterally across the Vienna Basin. This study suggests that this differential tectonic subsidence was caused by the paleostress regime changing by weakening transtension and strengthening E-W-directed extension toward the late Middle Miocene.

4. Axis of E-W trending extensional subsidence (Sarmatian-Pannonian; late Middle-Late Miocene). The tectonic subsidence of the Sarmatian-Pannonian was concentrated along the major driving faults. It was related to fault activity corresponding to the axis of E-W trending extension of the western parts of the Pannonian Basin system.

5. Axis of NE-SW trending transtensional subsidence (Quaternary). In the Quaternary, the Vienna Basin has been reactivated, and resulted in small basins subsided along the Vienna Basin transfer fault system.

Acknowledgments Open access funding provided by University of Vienna. We are grateful to the Dionyz Štur Institute, Slovakia, for providing us with data. Special thanks go to Andreas Beidinger and András Zámolyi who helped to collect and arrange the data. We acknowledge fruitful discussions with Kurt Decker on tectonical issues and Johannes Novotny on visualization techniques and two reviewers Sierd Cloetingh and Paul Mann for their constructive reviews. We also like to thank our colleagues and University of Vienna for their supports.

Open Access This article is distributed under the terms of the Creative Commons Attribution 4.0 International License (http://creativecommons.org/licenses/by/4.0/), which permits unrestricted use, distribution, and reproduction in any medium, provided you give appropriate credit to the original author(s) and the source, provide a link to the Creative Commons license, and indicate if changes were made.

\section{References}

Allen PA, Allen JR (2013) Basin analysis: principles and application to petroleum play assessment, 3rd edn. Wiley-Blackwell, Oxford Arzmüller G, Buchta S, Ralbovský E, Wessely G (2006) The Vienna basin. In: Golonka J, Picha FJ (eds) AAPG Memoir 84: the Carpathians and their foreland: geology and hydrocarbon resources. AAPG, Tulsa, pp 191-204

Báldi T (1980) The early history of Paratethys (in Hungarian with English abstract). Földt Közlöny 110:456-472

Baráth I, Kováč M, Hudáčková N, Hlavatý I (2003) The Karpatian in the Vienna Basin. In: Brzobohatý R, Cicha I, Kováč M, Rögl F (eds) The Karpatian - a lower miocene stage of the Central Paratethys. Masaryk University Press, Brno, pp 101-106
Beidinger A, Decker K (2011) 3D geometry and kinematics of the Lassee flower structure: implications for segmentation and seismotectonics of the Vienna Basin strike-slip fault, Austria. Tectonophysics 499:22-40

Beidinger A, Decker K (2014) Quantifying Early Miocene insequence and out-of-sequence thrusting at the Alpine-Carpathian junction. Tectonics 33:222-252

Čekan V, Kocák A, Tomek Č, Wessely G, Zych D (1990) Czechoslovak-Austrian cooperation in geophysical structural exploration in the Vienna basin. In: Minař́ková D, Lobitzer H (eds) Thirty years of geological cooperation between Austria and Czechoslovakia. Geol Surv, Prague, pp 23-31

Cloetingh S, Van der Beek PA, Van Rees D, Roep TB, Biermann C, Stephenson RA (1992) Flexural interaction and the dynamics of Neogene extensional basin formation in the Alboran-Betic region. Geo-Mar Lett 12:66-75

Cloetingh S, Ben-Avraham Z, Sassi W, Horváth F (1996) Dynamics of strike slip tectonics and basin formation. Tectonophysics 266: $1-523$

Cloetingh S, Bada G, Matenco L, Lankreijer A, Horváth F, Dinu C (2006) Thermo-mechanical modelling of the Pannonian-Carpathian system: modes of tectonic deformation, lithospheric strength and vertical motions. In: Gee D, Stephenson R (eds) Memoirs 32: European lithosphere dynamics. Geol Soc, London, pp 207-221

Csontos L, Nagymarosy A, Horváth F, Kováč M (1992) Tertiary evolution of the Intra-Carpathian area: a model. Tectonophysics 208:221-241

Decker K (1996) Miocene tectonics at the Alpine-Carpathian junction and the evolution of the Vienna Basin. Mitt Ges Geol Bergbaustud 41:33-44

Decker K, Peresson H (1996) Tertiary kinematics in the Alpine-Carpathian-Pannonian system: links between thrusting, transform faulting und crustal extension. In: Wessely G, Liebl W (eds) EAGE spec pub 5: oil and gas in alpidic thrustbelts and basins of Central and Eastern Europe. Geol Soc, London, pp 69-77

Decker K, Peresson H, Hinsch R (2005) Active tectonics and Quaternary basin formation along the Vienna Basin Transform fault. Quat Sci Rev 24:307-322

Dövényi P, Horváth F (1988) A review of temperature, thermal conductivity, and heat flow data for the Pannonian Basin. In: Royden LH, Horváth F (eds) AAPG memoir 45: the Pannonian Basin: a study in Basin Evolution. AAPG, Tulsa, pp 195-233

Fodor L (1995) From transpression to transtension: OligoceneMiocene structural evolution of the Vienna Basin and the East Alpine-Western Carpathian junction. Tectonophysics 242:151-182

Gardner GHF, Gardner LW, Gregory AR (1974) Formation velocity and density-the diagnostic basics for stratigraphic traps. Geophysics 39:770-780

Grenerczy G, Kenyeres A, Fejes I (2000) Present crustal movement and strain distribution in Central Europe inferred from GPS measurements. J Geophys Res 105:21835-21846

Hamilton W, Wagner L, Wessely G (2000) Oil and gas in Austria. Mitt Österr Geol Ges 92:235-262

Hinsch R, Decker K, Peresson H (2005) 3-D seismic interpretation and structural modeling in the Vienna Basin: implications for Miocene to recent kinematics. Austrian J Earth Sci 97:38-51

Hohenegger J, Ćorić S, Wagreich M (2014) Timing of the middle miocene Badenian stage of the central Paratethys. Geol Carpath 65:55-66

Hölzel M, Wagreich M, Faber R, Strauss P (2008) Regional subsidence analysis in the Vienna Basin (Austria). Austrian J Earth Sci 101:88-98

Hölzel M, Decker K, Zámolyi A, Strauss P, Wagreich M (2010) Lower Miocene structural evolution of the central Vienna Basin (Austria). Mar Petrol Geol 27:666-681 
Horváth F (1993) Towards a mechanical model for the formation of the Pannonian basin. Tectonophysics 226:333-357

Horváth F, Cloetingh S (1996) Stress-induced late-stage subsidence anomalies in the Pannonian basin. Tectonophysics 266:287-300

Huismans RS, Podladchikov YY, Cloetingh S (2001) Dynamic modelling of the transition from passive to active rifting, application to the Pannonian Basin. Tectonics 20:1021-1039

Jiříček R, Seifert P (1990) Paleogeography of the Neogene in the Vienna basin and the adjacent part of the foredeep. In: Minaříková D, Lobitzer H (eds) Thirty years of geological cooperation between Austria and Czechoslovakia. Geol Surv, Prague, pp 89-105

Jiřiček R, Tomek Č (1981) Sedimentary and structural evolution of the Vienna Basin. Earth Evol Sci 3-4:195-204

Kováč M, Holcová K, Nagymarosy A (1999) Paleogeography, paleobathymetry and relative sea-level changes in the Danube Basin and adjacent areas. Geol Carpath 50:325-338

Kováč M, Baráth I, Harzhauser M, Hlavatý I, Hudáčková N (2004) Miocene depositional systems and sequence stratigraphy of the Vienna Basin. Courier Forschungsinstitut Senckenberg 246:187-212

Kullmann E (1966) The role of neotectonic movements in the development of ground water reservoirs in the north-eastern part of the Vienna Basin. IAHS Redbook 120:392-400

Lankreijer A, Kováč M, Cloetingh S, Pitoňák P, Hlôška P, Biermann C (1995) Quantitative subsidence analysis and forward modelling of the Vienna and Danube basins: thin-skinned versus thickskinned extension. Tectonophysics 252:433-451

Lee EY (2015) Integrated basin analysis of the Vienna Basin, central Europe. Dissertation, University of Vienna

Lee EY, Zámolyi A, Beidinger A, Decker K, Strauss P (2011) Stratigraphy and subsidence history of the Závod region in the Slovak part of the central Vienna Basin. 73rd EAGE Conf \& Exhib, extended abstract, P253

Lee EY, Novotny J, Wagreich M (2016) BasinVis 1.0: a MATLAB ${ }^{\circledR}$ based program for sedimentary basin subsidence analysis and visualization. Comput Geosci 91:119-127. doi:10.1016/j. cageo.2016.03.013

Mann P, Hemptom MR, Bradley DC, Burke K (1983) Development of pull-apart basins. J Geol 91:529-554

Mann P, Taylor FW, Lawrence Edwards R, Ku TL (1995) Actively evolving microplate formation by oblique collision and sideways motion along strike-slip faults: an example from the northeastern Caribbean plate margin. Tectonophysics 246:1-69

Marion DP (1990) Acoustic, mechanical, and transport properties of sediments and granular materials. Dissertation, Stanford University

Miall AD (1999) Principles of sedimentary basin analysis, 3rd edn. Springer, Berlin

Monnet C, Bouchet S, Thiry-Bastien P (2003) ISOPAQ, a MATLAB program for stratigraphic and isopach mapping: example application to the French Bajocian (Jurassic) sediments. Comput Geosci 29:1101-1110

Ori GG, Friend PF (1984) Sedimentary basins formed and carried piggyback on active thrust sheets. Geology 12:475-478

Peresson H, Decker K (1997a) Far-field effects of Late Miocene subduction in the Eastern Carpathians: E-W compression and inversion of structures in the Alpine-Carpathian-Pannonian region. Tectonics 16:38-56

Peresson H, Decker K (1997b) The Tertiary dynamics of the northern Eastern Alps (Austria): changing palaeostresses in a collisional plate boundary. Tectonophysics 272:125-157

Picha FJ (1996) Exploring for hydrocarbons under thrust beltsa challenging new frontier in the Carpathians and elsewhere. AAPG Bull 80:1547-1564
Piller W, Harzhauser M, Mandic O (2007) Miocene Central Paratethys stratigraphy - current status and future directions. Stratigraphy $4: 151-168$

Plašienka D, Grecula P, Putiš M, Kováč M, Hovorka D (1997) Evolution and structure of the Western Carpathians: an overview. In: Grecula P, Hovorka D, Putiš M (eds) Geological evolution of the Western Carpathians. Mineralia Slovaca - Monograph, Bratislava, pp 1-24

Ratschbacher L, Merle O, Davy P, Cobbold P (1991a) Lateral extrusion in the eastern Alps, part I: boundary conditions and experiments scaled for gravity. Tectonics 10:245-256

Ratschbacher L, Frisch W, Linzer HG (1991b) Lateral extrusion in the eastern Alps, part II: structural analysis. Tectonics 10:257-271

Royden LH (1985) The Vienna Basin: a thin-skinned pull-apart basin. In: Biddle KT, Christie-Blick N (eds) SEPM Spec Pub 37: strikeslip deformation, basin formation, and sedimentation. SEPM, Tulsa, pp 319-338

Royden LH (1988) Late Cenozoic tectonics of the Pannonian basin system. In: Royden LH, Horváth F (eds) AAPG Memoir 45: the Pannonian Basin. A study in Basin evolution. AAPG, Tulsa, pp $27-48$

Royden LH, Horváth F, Rumpler J (1983a) Evolution of the Pannonian Basin System: 1. Tectonics. Tectonics 2:63-90

Royden LH, Horváth F, Nagymarosy A, Stegena L (1983b) Evolution of the Pannonian Basin System: 2. Subsidence and thermal history. Tectonics 2:91-137

Sachsenhofer R (2001) Syn- and post-collisional heat flow in the Cenozoic Eastern Alps. Intern J Earth Sci 90:579-592

Sachsenhofer RF, Lankreijer A, Cloetingh S, Ebner F (1997) Subsidence analysis and quantitative basin modelling in the Styrian Basin (Pannonian Basin System, Austria). Tectonophysics 272:175-196

Salcher BC, Meurers B, Smit J, Decker K, Hölzel M, Wagreich M (2012) Strike-slip tectonics and Quaternary basin formation along the Vienna Basin fault system inferred from Bouguer gravity derivatives. Tectonics 31:TC3004

Sanchez J, Mann P, Emmet PA (2015) Late Cretaceous-Cenozoic tectonic transition from collision to transtension, Honduran Borderlands and Nicaraguan Rise, NW Caribbean Plate boundary. In: Nemčok M, Rybár S, Sinha ST, Hermeston SA, Ledvényiová L (eds) Spec Pub 431: transform margins: development, controls and petroleum systems. Geol Soc, London. doi:10.1144/SP431.3

Sauer R, Seifert P, Wessely G (1992) Part I: Outline of Sedimentation, Tectonic Framework and Hydrocarbon Occurrence in Eastern Lower Austria. In: Guidebook to Excursions in the Vienna Basin and the adjacent Alpine-Carpathian thrustbelt in Austria. Mitt Österr Geol Ges 85:5-96

Sclater JG, Christie PAF (1980) Continental stretching: an explanation of the post-mid-Cretaceous subsidence of the central North Sea basin. J Geophys Res 85:3711-3739

Sclater JG, Royden L, Horváth F, Burchfiel BC, Semken S, Stegena L (1980) The formation of the intra-Carpathian basins as determined from subsidence data. Earth Planet Sci Lett 51:139-162

Seifert P (1992) Palinspastic reconstruction of the easternmost Alps between upper Eocene and Miocene. Geol Carpath 43:327-331

Seifert P (1996) Sedimentary-tectonic development and Austrian hydrocarbon potential of the Vienna Basin. In: Wessely G, Liebl W (eds) EAGE Spec Pub 5: Oil and Gas in Alpidic Thrustbelts and Basins of Central and Eastern Europe. Geol Soc, London, pp 331-341

Steckler MS, Watts AB (1978) Subsidence of the Atlantic-type continental margin off New York. Earth Planet Sci Lett 41:1-13

Strauss P, Harzhauser M, Hinsch R, Wagreich M (2006) Sequence stratigraphy in a classic pull-apart basin (Neogene, Vienna Basin). A 3D seismic based integrated approach. Geol Carpath 57:185-197 
Van Hinte JE (1978) Geohistory analysis - Application of micropaleontology in exploration geology. AAPG Bull 62:201-222

Vass D, Pereszlényi M, Kováč M, Král M (1990) Outline of Danube basin geology. Földt Közlöny 120:193-214

Wagreich M, Schmid HP (2002) Backstripping dip-slip fault histories: apparent slip rates for the Miocene of the Vienna Basin. Terra Nova 14:163-168

Weissenbäck M (1996) Lower to Middle Miocene sedimentation model of the central Vienna Basin. In: Wessely G, Liebl W (eds) EAGE Spec Pub 5: Oil and Gas in Alpidic Thrustbelts and Basins of Central and Eastern Europe. Geol Soc, London, pp 355-363
Wessely G (1988) Structure and development of the Vienna basin in Austria. In: Royden LH, Horváth F (eds) AAPG memoir 45: the Pannonian Basin: a study in basin evolution. AAPG, Tulsa, pp 333-346

Wessely G, Kröll A, Jiřriček R, Nemec F (1993) Wiener Becken und angrenzende Gebiete-Geologische Einheiten des präneogenen Beckenuntergrundes. Geologische Themenkarte der Republik Österreich 1:200.000, Geologische Bundesanstalt, Vienna

Xie X, Heller PL (2009) Plate tectonics and basin subsidence history. Geol Soc Am Bull 121:55-64 